\title{
Does Integrated Sources of Nutrients Enhance Growth, Yield, Quality and Soil Fertility of Vegetable Crops?
}

\author{
Mukesh Kumar ${ }^{1 *}$, Veena Chaudhary ${ }^{2}$, R.K. Naresh ${ }^{3}$, O.P. Maurya ${ }^{4}$ and S.L. Pal ${ }^{4}$ \\ ${ }^{1}$ Department of Horticulture, Sardar Vallabhbhai Patel University of Agriculture and \\ Technology, Meerut, UP-250110, India \\ ${ }^{2}$ Department of Chemistry, CSSS (PG) College, Machhra, Meerut, UP-250106, India \\ ${ }^{3}$ Department of Agronomy, Sardar Vallabhbhai Patel University of Agriculture and \\ Technology, Meerut, UP-250110, India \\ ${ }^{4} R S M(P G)$ College, Dhampur, Bijnor, UP-246761, India \\ *Corresponding author
}

\section{Keywords}

Organic manure, Inorganic fertilizers, Bio-fertilizers, INM, Soil quality, Vegetable crops

Article Info

Accepted:

02 May 2018

Available Online:

10 June 2018

\section{A B S T R A C T}

In order to meet the growing demand of vegetables, agricultural land per unit area required to achieve maximum efficiency and highest quality product. It is well known fact that nutrition of plant is one of the most important factors to control agricultural productivity and quality. It has been well documented that rates of nutrients in the soil affect the quality and yield of crops. Probably the soil environment is the most vulnerable to the direct effects of these practices in modern agriculture. Excessive use of inorganic fertilizers could destroy the fertility of the soil in a long run which compels the scientific community to look for the alternatives like organic farming and integrated use of organic and inorganic fertilizers. To achieve the target, integrated sources of nutrient may be useful in resolving these concerns, which has been proposed as a promising strategy for addressing these challenges. INM has multifaceted potential for the improvement of plant performance, resource efficiency and also enabling the protection of the environment and resource quality. Lower inputs of chemical fertilizer and therefore lower human and environmental costs (such as intensity of land use, $\mathrm{N}$ use, reactive $\mathrm{N}$ losses and GHG emissions) were achieved under advanced INM practices without any negative effect on crop yields. The role and importance of inorganic fertilizers in combination with organic manures and biofertilizers in sustainable crop growth, production, quality and soil health has been reviewed by several authors. The findings of different workers revealed that the integrated sources of nutrients increased growth, yield and quality of vegetables as compared with conventional methods as sole application of $100 \%$ recommended dose of chemical fertilizers. The results also demonstrated that the integrated sources of nutrients practices increase nutrient use efficiency and improve soil health and sustainability. Strong and convincing evidence indicates that INM practice could be an innovative and environment friendly practice for sustainable growth, yield and quality of vegetables. 


\section{Introduction}

The country's horticulture production rose by 5 per cent to touch an all-time high of 300 million tonnes during 2016-17 on the back of record output of fruits, vegetables, spices and plantation crops. India is the second largest producer of vegetables, next only to China. China accounts for $45 \%$ of the global value of vegetable production and India comes second, accounting for $8 \%$ production of vegetables (FAO, 2017).

Vegetable production rose by 4 per cent in India and reached up 176 million tonnes in 2016-17 (Ministry of Agriculture and Farmers Welfare, 2017). Among vegetables, onion production rose by nearly 4 per cent to 21.7 million tonnes. Tomato output, too, grew by 4 per cent to around 19.5 million tonnes. The major onion growing and producer states are Madhya Pradesh, Andhra Pradesh, Karnataka, Odisha and Gujarat, Maharashtra and Bihar. The country witnessed record potato output at 48.2 million tonnes in 2016-17 from 43.4 million tonnes in the previous year. Uttar Pradesh, West Bengal, Bihar, Gujarat, Madhya Pradesh and Punjab are major producing states.

Our demand of vegetable will be 250 million ton by 2020 AD (Singh, 2000), whereas, the expected production at present is about 160 million tonne and annually $0.8 \%$ of agricultural land being usurped for urbanization (Kar, 2002). The increase in vegetable production by increasing area under vegetable cultivation is limited due to continued decrease of land holdings. Hence, it is essential to increase vegetable productivity by application of fertilizers to fulfil country's requirements for food and nutrition security and poverty alleviation. The modernization of agriculture is one of the most important factors for increasing the use of agrochemicals. The use of chemicals in agriculture started with the use of fertilizers. Agro-chemicals enabled man to control the plant growth and have become the greatest tool in the hand of horticulture for increasing yield and better quality vegetables.

Integrated plant nutrient management is the intelligent use of optimum combination of organic, inorganic and biological nutrient sources in a specific crop, cropping system and climatic situation so as to achieve and to sustain the optimum yield and to improve or to maintain the soil's physical, biological and chemical properties. Such a crop nutrition package has to be technically sound, economically attractive, practically feasible and environmentally safe (Hedge and Rudragouda, 2003). The program also involves maximize biological inputs to crop production and minimize the use of inorganic amendments so as to create a much more sustainable pattern of crop production, not only ecologically but also environmentally (National Research Council, 1991).

Integrated Nutrient Management in vegetable crops is very important to address the issues like poor quality of vegetables in terms of nutritional value, low yield and production. One of the factors affecting the productivity in most of the vegetable crops is improper use of nutrients. To improve the productivity, quality and soil fertility by adequate amount of fertilizers in balanced proportion should be used which has been given less attention by the vegetable growers.

\section{Why integrated nutrient management is needed in vegetable crops?}

INM is very essential to address the following issues:

The decline in productivity can be attributed to the appearance of deficiency in secondary and micronutrients. 
The physical condition of the soil is deteriorated as a result of long-term use of chemical fertilizers. The recent energy crisis, high fertilizer cost and low purchasing power of the farming community have made it necessary to rethink alternatives.

Unlike chemical fertilizer, organic manure and bio-fertilizer are available locally at cheaper rates

\section{Principles of Integrated Nutrient Management (INM)}

The main principle of INM is to maximize biological potential for improving crop productivity and resources use efficiency through root zone/rhizosphere management. Plant roots take up nutrients from soils via the rhizosphere, a narrow zone of the soil that is directly influenced by root growth, root secretions, and associated soil microorganisms (Zhang et al., 2012). The rhizosphere is the important interface where interactions among plants, soils, and microorganisms occur and is a "bottleneck" controlling nutrient transformations, availability, and flow from soils to plants. Therefore, the chemical and biological processes occurring in the rhizosphere determine the mobilization and acquisition of soil nutrients together with microbial dynamics, and also control nutrients use efficiency by crops, and thus profoundly influence cropping system productivity and sustainability (Zhang et al., 2004, 2010, 2011, 2012). The principle of INM is to control the $\mathrm{N}$ losses and their harmful environmental effects, while achieving high crop productivity (Gruhn et al., 2000).

The fate of $\mathrm{N}$ in field is an integrated consequence of crop $\mathrm{N}$ uptake, immobilization and residues in the soil, and $\mathrm{N}$ losses to the environment, such as ammonia volatilization, NOX emissions, denitrification, $\mathrm{N}$ leaching and runoff (Witt and Dobermann, 2004).

\section{Advantages of INM}

Enhances the availability of applied as well as native soil nutrients.

Synchronizes the nutrient demand of the crop with nutrient supply from native and applied sources.

Provides balanced nutrition to crops and minimizes the antagonistic effects resulting from hidden deficiencies and nutrient imbalance.

Improves and sustains the physical, chemical and biological functioning of soil.

Minimizes the deterioration of soil, water and ecosystem by promoting carbon sequestration, reducing nutrient losses to ground and surface water bodies and to atmosphere

\section{Disadvantages of INM}

Organic sources used in INM are comparatively low in nutrient content, so larger volume is needed to provide enough nutrients for crop growth.

The nutrient composition of compost and FYM is highly variable; the cost is high as compared to chemical fertilizers.

Integrated nutrient management system is more labourers intensive as compared to the conventional methods.

\section{Components of INM}

\section{Organic Manures}

Organic manures are valuable by-products of farming and allied industries, derived from plant and animal sources. These manures have the advantage of supplying secondary and micro nutrient along with NPK, which is 
important for sustained production. The commonly used organic manures are Farm Yard Manure (FYM), Enriched Organic Manure, Vermicompost, Poultry Manure, Biogas Slurry, Urine and Liquid Manure etc.

\section{Green manuring}

Green manure crops are grown usually for restoring or enhancing soil organic matter content, properties of soil and nitrogen content in the soil and their use in cropping system is called green manuring.

Legumes are generally used as green manure crops due to their ability to fix atmospheric nitrogen in the root nodules through symbiotic association with a bacterium.

The following plants are commonly used for preparing of green manures, i.e. cowpea, dhaincha, sunhemp, karanj etc.

\section{Biofertilizers}

Biofertilizer is a substance which contains living microorganisms which, when applied to seeds, plant surfaces, or soil, colonize the rhizosphere or the interior of the plant and promotes growth by increasing the supply or availability of primary nutrients to the host plant.

Biofertilizers can be grouped in to five catagories (Barman et al., 2017)

Nitrogen $\left(\mathbf{N}_{2}\right)$ fixing biofertilizers: it can be sub group in three category

Free-living- Example, Azotobacter, Clostridium, Anabaena, Nostoc

Symbiotic - Example, Rhizobium, Frankia, Anabaena azollae

Associative Symbiotic- Example, Azospirillum

\section{P-solubilizing biofertilizers}

Bacteria- Example, Bacillus megaterium var. phosphaticum, Bacillus circulans, Pseudomonas striata

Fungi- Example, Penicillium sp., Aspergillus awamori

\section{P-mobilizing biofertilizers}

Arbuscular mycorrhiza- Example, Glomus sp., Gigaspora sp., Acaulospora sp., Scutellospora sp., Sclerocystis $s p$.

Ectomycorrhiza -Example, Laccaria sp., Pisolithus sp., Boletus sp., Amanita sp.

Orchid mycorrhiza - Example, Rhizoctonia solani

\section{Biofertilizers for micro nutrients}

Silicate and zinc solubilizers. Example, Bacillus sp.

\section{Plant growth promoting rhizobacteria}

Pseudomonas. Example, Pseudomonas fluorescens

Different methods of integrated sources of nutrients in crops

Combined use of chemical and organic fertilizers

The integrated nutrient management system is an alternative and is characterized by reduced input of chemical fertilizers and combined use of chemical fertilizers with organic materials such as animal manures, crop residues, green manure and composts. Management systems that rely on organic inputs as plant nutrient sources have different dynamics of nutrient availability from those involving the use of 
chemical fertilizers. For sustainable crop production, integrated use of chemical and organic fertilizer has proved to be highly beneficial.

\section{Combined use of bio-fertilizers with chemical or organic fertilizers}

In this system, the nutrients provided to the crops by combined use of i.e. biofertilizers, chemical fertilizers and organic materials such as animal manures, crop residues, green manure and composts.

\section{Effect of integrated sources of nutrients on soil quality of vegetable crops}

Reddy and Reddy (1999) noted significant increases in micronutrients in field soils after vermicompost applications as compared to those soils treated with animal manures. However, Khatic and Dikshit (2001) concluded that organic manures viz., FYM @ $10 \mathrm{t} \mathrm{ha}^{-1}$ and compost @ $10 \mathrm{t} \mathrm{ha}^{-1}$ increased the available P status in clay soils. Similarly, Sharma and Raghu (2003) conducted an experiment to assess the effect of integrated sources of nutrients on soil quality. They reported that the integrated treatment containing FYM $6 \mathrm{t}+20 \mathrm{~kg} \mathrm{~N}+13 \mathrm{~kg}$ P2O5 ha-1 had highly sustainable for significant build up of organic carbon, available $\mathrm{N}$ and $\mathrm{P}$ status in Vertisols. Ghosh and Sarkar, (2000) revealed that treatment contains vermicompost had higher nutrients and microbial population in harvested soil. They further reported that one tonne of compost material can supply adequate nutrients i.e. $15 \mathrm{~kg}$ nitrogen $(\mathrm{N}), 8 \mathrm{~kg}$ phosphorus $\left(\mathrm{P}_{2} \mathrm{O}_{5}\right)$ and $10 \mathrm{~kg}$ potash $\left(\mathrm{K}_{2} \mathrm{O}\right)$ which can substitute of chemical fertilizer. The findings also demonstrated that compost application had increase the yield by 11.1 per cent with mature compost and 11.7 per cent with fresh compost when compared to fertilizer controlled plots. Bhardwaj et al., (2002) reported that the application of organics including biofertilizers improved the physico-chemical and biological properties of the soils. The microbial population varied between $4.9 \times 107$ to $6.6 \times 107 \mathrm{cfu} / \mathrm{g}$ soils with a predominance of bacterial count under mid hill conditions. Chaudhary et al., (2003) grown cabbage cv. Golden Acre under the organic manures viz. vermicompost (100 and $200 \mathrm{~g} /$ plant $)$ and FYM (250 and $500 \mathrm{~g} /$ plant) as a solo or compound application and analyzed the soil properties of each treated plot. They observed that soil bulk density had decreased with all the organic treatments and the lowest value was obtained through VC @ 200 g/plant + FYM @ 250 g/plant. The highest soil organic carbon was obtained with VC @ 100 g/plant + FYM at 500 g/plant. The maximum available $\mathrm{N}$ was observed in VC @ 200 g/plant + FYM @ 250 g/plant, while maximum K was at VC @ $100 \mathrm{~g} /$ plant + FYM (a) 500 g/plant. Tanwar and Shaktawat (2004) opined that application of FYM at $10 \mathrm{t} \mathrm{ha}^{-1}$ (with and without PSB) improved the $\mathrm{N}$ status of soil but the P status at the end of system was less over initial status. However, Singh et al., (2004) revealed that there was an increase in available nitrogen in soil after each harvest was observed. Inoculation of PSB and VAM significantly increased the availability of phosphorus in soil, with marginal decline in bulk density. Kumar et al., (2006) found that application of $50 \% \mathrm{~N}+10 \mathrm{t}$ FYM had significantly higher nutrient uptake (122.0, 37 and $110 \mathrm{~kg}$ of NPK ha- ${ }^{-1}$, respectively) and availability (248, 50 and $245 \mathrm{~kg}$ of NPK ha ${ }^{-1}$, respectively) in soil. An experiments conducted by Ramesh et al., (2008) to assess the effect of organic and inorganic on soil quality. The findings showed significant improvement in soil organic carbon, available $\mathrm{N}, \mathrm{P}, \mathrm{K}$ status and enzyme activity of soil (dehydrogenase and phosphatase activity) with organic manure treatments compared to chemical fertilizers alone after three year of experiments. Singh et al., (2008) found that application of either cattle dung manure + 
poultry manure or cattle dung manure + vermicompost + poultry manure combinations recorded significantly higher soil organic carbon (0.64 \%), dehydrogenase (132 mg $\mathrm{TPF} / \mathrm{kg}$ soil / $124 \mathrm{~h}$ ) and phosphatase (82 mg p-nitro phenol / kg soil / h) and soil microbial biomass carbon content ( $348 \mathrm{mg} \mathrm{kg}^{-1}$ soil) at the end of crop cycle compared to control. Gunjal et al., (2010) noticed that recommended dose of fertilizer when applied with organics i.e. FYM $5 \mathrm{t} \mathrm{ha}^{-1}$ had significantly higher total uptake of $\mathrm{N}, \mathrm{P}$ and $\mathrm{K}$ (218, 28.48 and $125.51 \mathrm{~kg} \mathrm{ha}^{-1}$, respectively) over the control $(135.84,14.66$ and $82.68 \mathrm{~kg}$ NPK ha ${ }^{-1}$, respectively). Adeleye et al., (2010) analyzed the effect of poultry manure ( 0 t/ha and $10 \mathrm{t} / \mathrm{ha}$ ) on physico-chemical properties of soil in Ondo, Nigeria. The findings indicated that poultry manure application improved soil physical properties, increased total porosity and soil moisture retention capacity. The same treatment also reduced soil bulk density and temperature. The treatment consisting poultry manure ( 0 t/ha and 10 t/ha improved soil organic matter, total $\mathrm{N}$, available $\mathrm{P}$, exchangeable $\mathrm{Mg}, \mathrm{Ca}, \mathrm{K}$ and lowered exchange acidity. Therefore, the use of poultry manure in crop production was recommended and suggested that it will ensure stability of soil structure; improve soil organic matter status and nutrients availability. Incorporation of organic fertilizers can also increase microbial activity in soils between $16 \%$ and $20 \%$ as compared to inorganic fertilizers (Gonzalez et al., 2010). Ceronio et al., (2012) reported that compost and organic manure seamed to improve the chemical properties of soil more than chicken manure. Kumar, (2012) studied the effect of integrated nutrient management on soil health and productivity of potato (Solanum tuberosum L.) under rainfed condition. The results showed that $50 \%$ of the recommended dose of NPK through inorganic $+50 \%$ recommended dose of nitrogen (RDN) through organic manures (FYM, PM or VC) or $100 \%$ recommended dose of NPK through inorganic fertilizers alone favorably influenced the tuber yield, nutrient uptake, soil fertility and paid higher returns compared to other treatments. Seed treatment with Azotobactor + PSB proved better in tuber yield, nutrient uptake and recorded higher returns as compared to sole treatment of either Azotobactor or PSB. Total organic carbon (TOC), soil microbial biomass carbon (SMBC), available $\mathrm{N}, \mathrm{P}$, and $\mathrm{K}$ status of the soil after 3 years were maximum when $50 \%$ recommended dose of NPK were applied through inorganic and remaining $50 \%$ RDN through PM. Dey et al., (2015) studied the effect of different levels and combinations of organics viz. crop residue, bio-fertilizer, FYM alone and in combination with chemical fertilizers viz., 0, 50, 100 and $150 \%$ of recommended dose of fertilizer (RDF) were tested. The mean effect of different organic treatments on improvement of soil physical properties were nearly similar the treatments containing $50 \%$ organics $+50 \%$ inorganic (INM). However, Avhad et al., (2016) conducted a study to determine the influence of organic and inorganic fertilizers on soil quality parameters of tomato hybrid Phule Raja. The residual soil fertility in respect to organic carbon was improved significantly by various treatments. The integrated treatment consisting RDF 300:150: $150 \mathrm{~kg}$ NPK and $20 \mathrm{t}$ FYM ha-increased the organic carbon $(0.62$ $\%)$, total nutrient uptake of nitrogen $(98.50 \mathrm{~kg}$ $\left.\mathrm{ha}^{-1}\right)$, phosphorus $\left(49.70 \mathrm{~kg} \mathrm{ha}^{-1}\right)$, potassium (123.30 $\left.\mathrm{kgha}^{-1}\right)$, fe $\left(201.94 \mathrm{mg} \mathrm{kg} \mathrm{kg}^{-1}\right), \mathrm{Mn}$ (39.50 mg kg-1), cu (46.13 $\mathrm{mg} \mathrm{kg}^{-1}$ ) and $\mathrm{Zn}$ (51.67 mg kg-1). Kumar, (2016) reported that different treatments showed significant variations in soil quality i.e. $(\mathrm{P}<0.05 / \mathrm{P}<0.01)$ EC, OC, TKN, $\mathrm{PO}_{4}{ }^{3}-, \mathrm{Na}+, \mathrm{K}+, \mathrm{Ca}^{2+}, \mathrm{Mg}^{2+}$, $\mathrm{Cd}, \mathrm{Cr}, \mathrm{Cu}, \mathrm{Fe}, \mathrm{Mn}$ and $\mathrm{Zn}$ of the soil. All the treatments were recorded to be effective to increase the macro and micro essential nutrients in the soil in comparison to control. Among all the treatments, the most increase of EC, OC, TKN, $\mathrm{PO}_{4}{ }^{3-}, \mathrm{Na}+, \mathrm{K}+, \mathrm{Ca}^{2+}, \mathrm{Mg}^{2+}$, 
$\mathrm{Cd}, \mathrm{Cr}, \mathrm{Cu}, \mathrm{Fe}, \mathrm{Mn}$ and $\mathrm{Zn}$ of the soil was recorded with 50\% RDF + vermicompost @ 5 t ha ${ }^{-1}$. Kumar et al., (2017) assessed the effect of integrated nutrient management on soil enzymes, microbial biomass carbon and microbial population under okra cultivation. The results of the study indicated that there was the improvement in soil biological properties and soil enzymes in all plots over the initial value. The highest biological properties like Microbial Biomass Carbon (MBC) (244.86 $\left.\mu \mathrm{g} \mathrm{g}^{-1}\right)$, bacterial population (8.24 log $\mathrm{cfug}^{-1}$ soil), fungal population (3.89 $\log$ cfu $\mathrm{g}^{-1}$ soil), soil enzymes like fluorescein di-acetate (FDA) $\left(7.28 \mu \mathrm{g}\right.$ fluorescein $\mathrm{g}^{-1}$ soil $\left.\mathrm{h}^{-1}\right)$, phosphomonoesterase (PME) $(50.15 \mu \mathrm{g}$ p-nitrophenol $\mathrm{g}^{-1} \mathrm{~h}^{-1}$ ), Deydrogenase (DH) (136.90 $\mu \mathrm{g}$ TPF g ${ }^{-1}$ soil $24 \mathrm{~h}^{-1}$ ), Arylsulphatase $\left(14.16 \mu \mathrm{g} \quad \mathrm{p}\right.$-nitrophenol $\mathrm{g}^{-1} \mathrm{~h}^{-1}$ ) and Arylesterase activity (113.92 $\mu \mathrm{g}$ p-nitrophenol $\mathrm{g}^{-1} \mathrm{~h}^{-1}$ ) found in the treatment when plants were treated with $50 \%$ recommended dose of $\mathrm{N}, \mathrm{P}, \mathrm{K}+$ Vermicompost @ $2 \mathrm{t} \mathrm{ha}^{-1}$ (mixed with microbial consortium). Increased in microbial population and soil enzymatic activity is the indicator of good soil condition for crop growth. Therefore, the addition of organic manure and biofertilizers along with the reduced amount of inorganic fertilizers should be advocated for maintaining high soil quality for longer the period. While, Tekale et al., (2017) conducted two year trails to study the effect of Integrated Nutrient Management (INM) on availability of nutrients in soil, nutrient uptake and yield of tomato (Lycopersicon esculentum Mill.) cv. Gujarat Tomato-2. The results of two year experiment and their pooled data indicated that integrated treatments consisting FYM $20 \mathrm{t} \mathrm{ha}^{-1}+100 \%$ RDF had significantly the highest available $\mathrm{N}$ $\left(255,259\right.$ and $\left.257 \mathrm{~kg} \mathrm{ha}^{-1}\right), \mathrm{P}_{2} \mathrm{O}_{5}(63.5,61.9$ and $\left.62.7 \mathrm{~kg} \mathrm{ha}^{-1}\right), \mathrm{K}_{2} \mathrm{O}(327,322$ and $325 \mathrm{~kg}$ $\left.\mathrm{ha}^{-1}\right)$ nutrient in soil after harvest, $\mathrm{N}(1.54$, 1.56 and $1.55 \%), \mathrm{P} 2 \mathrm{O} 5(0.49,0.50$ and 0.50 $\%), \mathrm{K}_{2} \mathrm{O}(1.30,1.33$ and $1.32 \%)$ nutrient content in tomato plant, total nutrient uptake $\mathrm{N}$
(136, 145 and $\left.140 \mathrm{~kg} \mathrm{ha}^{-1}\right), \mathrm{P}(45.2,49.8$ and $\left.47.5 \mathrm{~kg} \mathrm{ha}^{-1}\right), \mathrm{K}\left(66,76\right.$ and $\left.71 \mathrm{~kg} \mathrm{ha}^{-1}\right)$, fruit yield plant ${ }^{-1}(1.49,1.58$ and $1.54 \mathrm{~kg})$ and fruit yield $\operatorname{plot}^{-1}(29.86,31.56$ and $30.71 \mathrm{~kg})$.

\section{Effect of integrated sources of nutrients on quality of vegetables}

Chinnaswami and Mariakulandai, (1966) conducted an experiment to assess the influence of organic and inorganic manures on the firmness and storage life of tomato. The findings revealed that combined application of FYM and inorganic mixture increased the ascorbic acid and protein content as compared with groundnut cake and inorganic fertilizer alone. They also observed the keeping quality and storage life was better with combined application of FYM and inorganic mixture. Sujatha and Krishnappa, (1995) reported that the highest starch, crude protein and reducing sugars as well as total sugars with 120: 100: $120 \mathrm{~kg} \mathrm{NPK} \mathrm{ha}{ }^{-1}+50 \mathrm{t}$ FYM. While, Lisiewska and Kmiecik, (1996) reported that increasing the amount of nitrogen fertilizer from 80 to $120 \mathrm{~kg} \mathrm{ha}^{-1}$ decreased the vitamin $\mathrm{C}$ content by $7 \%$ in cauliflower. It means organic treatment can increase the yield and quality of crop. According to Mahendran and Kumar, (1997), the size and net weight of cabbage could be significantly influenced with the application organic manures. Highest TSS and ascorbic acid contents were observed with $75 \%$ of the recommended rate of NPK integrated with digested organic supplement and vermicompost. However, the results of Kumaran et al., (1998) showed that a combination of organic and inorganic fertilizers gave the best results in terms of yield in tomato. The quality parameters such as TSS and ascorbic acid contents were comparatively higher in organically grown tomato plants. An experiment conducted by Mahendran and Kumar, (1998) to evaluate the effect of inorganic with biofertilizers on cabbage. Maximum starch and crude protein 
content obtained from the plants treated with $100 \%$ recommend dose of NPK with combination of Azospirillum and Phosphobacterium. Nanthakumar and Veeraragavathatham, (1999) reported that combined application of FYM, Azospirillum and phosphobacteria + inorganic fertilizers favourably influence the keeping quality of brinjal with respect to lower cumulative physiological loss in weight, improved general appearance and overall high acceptance over application of inorganic fertilizer alone. Lee and Kadeer, (2000) also reported that nitrogen fertilizers at high rates tend to decreased the vitamin $\mathrm{C}$ content in many vegetables. Raj and Kumari, (2001) observed that combined application of FYM and neem cake (1:1) produced lower crude fibre content and best keeping quality in okra fruits. However, maximum crude protein content $(17.95 \%)$, minimum crude fibre content $(12.58 \%)$ and best keeping quality (5.68 days) obtained by application of organic manures and Azospirillum inoculation. Likewise, Harikrishna et al., (2002) recorded the highest fruit yield $\left(54.32 \mathrm{t} \mathrm{ha}^{-1}\right)$ with the application of 25 t FYM ha ${ }^{-1}+75 \% \mathrm{~N}+100 \% \mathrm{P}+100 \%$ K. Similarly, Patil et al., (2004) noticed the maximum number of fruits, heaviest fruit yield plant ${ }^{-1}$, yield plot $^{-1}$, TSS and ascorbic acid contents in tomato under the treatment of $50 \%$ RDF + $50 \%$ FYM. Kamili et al., (2002) assessed the fruit quality of brinjal (Solanum melongena L.) when plants treated with microbial inoculants and chemical fertilizers. The findings reported that the application of Azospirillum $+100 \mathrm{~kg} \mathrm{~N} / \mathrm{h}$ resulted maximum vitamin $\mathrm{C}^{\prime}$ content in brinjal fruits. In case of organically managed soil, plants are generally exposed with comparatively lower amount of nitrogen and several plant nutrients are released slowly over time. Therefore, organic crop would be expected to maintain higher vitamin ' $\mathrm{C}$ ' and carbohydrates and less protein as reported by Bahadur et al., (2003) in broccoli. Kadalag et al., (2007) worked on yield and quality of tomato fruits as influenced by bio-fertilizers. The studied data exhibited that application of recommended dose along with Azotobacter recorded higher quality parameter of tomato such as TSS $\left(6.23{ }^{\circ} \mathrm{B}\right)$, reducing sugar (2.89), acidity (0.63), vitamin $\mathrm{C}(15.2 \mathrm{mg} / 100 \mathrm{~g})$ and lycopene $(\mathrm{mg} / 100 \mathrm{~g})$ as compared to other treatment. Wang et al., (2010) observed significantly higher contents of vitamin $\mathrm{C}$, phenols and flavonoids when Chinese cabbage cultivated in plastic pots filled with the vermicompost: soil mixtures with ratios the 4:7 and found 5.8- fold higher than that of full soil treatment. Toor et al., (2010) used different types of fertilisers and observed the decreased in vitamin $\mathrm{C}$ content of tomatoes by high $\mathrm{NO}_{3}^{-}$levels. An experiment conducted by Azin and Dhuma, (2012) to study the effect of organic manure on growth, yield and quality of tomato. The results indicated that the amendment of organic manures like Neemcake $(2 \mathrm{~kg})$ and Jeevamrutha (cow dung $10 \mathrm{~kg}+$ jaggery $2 \mathrm{~kg}$ + cow urine 5 liter) found to be highly significant to improve growth and yield attributes. The nutrient quality of analysis indicated the superiority of organically grown tomato in terms of total carbohydrates, proteins and vitamin $\mathrm{C}$. The findings confirmed that the treatment of organic manures had positive influence on growth and yield attributes of tomato over inorganic fertilizers. Mitova et al., (2014) studied the influence of organic, mineral and organic mineral fertilization on the growth, development, yield and some quality indicators for early potatoes. The highest yield $\left(32.42 \mathrm{t} \mathrm{ha}^{-1}\right)$ was obtained under the mixed fertilization regime. As regards quality indicators, the biggest tubers (101.42 $\mathrm{g} \mathrm{tuber}^{-1}$ ) were obtained under the mixed fertilization regime with high content of total sugars $5.1 \%$. Shree et al., (2014) found maximum ascorbic acid (63.12) when plants were grown under the treatment containing $1 / 2 \mathrm{~N}: \mathrm{P}: \mathrm{K}$ (recommended doses of NPK+ FYM 5t/ha + 
poultry manure 2t/ha+ Azospirillum in cauliflower. Similar results were also reported by Singh et al., (2014) who found maximum TSS $\left(4.97^{\circ} \mathrm{B}\right)$ and reducing sugar contents with the application of 100 per cent $\mathrm{N}$ from Poultry manure fallowed by, 100 per cent from vermicompost $\left(10 \mathrm{t} \mathrm{ha}^{-1}\right)$. Avhad et al., (2016) conducted a study to determine the influence of organic and inorganic fertilizers on quality parameters of tomato hybrid Phule Raja. The findings exhibited non-significant effect on parameters viz., TSS, acidity, total sugars, reducing sugars, non-reducing sugars, sugar: acid ratio etc. Nurhidayati et al., (2016) used the vermicompost prepared from the mixture of cow manure and vegetable residue combined with inoculation of earthworm $P$. corethrurus by $0-25$ indiv m-2. The treatment had the highest contents of vitamin $\mathrm{C}$ with increase of $12 \%$. The vermicompost consisting the mixture of cow manure and leaf litter combined with inoculation of earthworm $P$. corethrurus by $25-50$ indiv $\mathrm{m}-2$ had the highest sugar content, with increase of $57 \%$ compared to the inorganic treatment. While, Goswami et al., (2017) reported that use of VC and DC in combination with recommended chemical fertilization effectively stimulated crop growth, yield, product quality, and storage longevity for both tomato and cabbage. Sachan et al., (2017) studied the quality parameters of Okra (Abelmoschus esculentus L.) as influenced by the integrated nutrient management. The results revealed that the plants treated with NPK@ $@ 75 \%+F Y M @ 2.5$ tn/ha + Poultry manure @2.5tn/ha + Vermi- compost @ 2.5tn/ha significantly exhibited maximum protein content $(16.61 \%)$ and TSS $\left(2.44^{\circ}\right.$ Brix) as quality parameters while the treatment control showed lowest response. Kiraci, (2018) used cow manure, sheep manure, poultry manure, seaweed, and conventional applications to assess the effect on growth and quality of carrots. The findings revealed that five-ton poultry manure application gave the highest $\left(5.91 \quad \mathrm{t} / \mathrm{ha}^{-1}\right) \quad$ whereas, control application was the lowest $\left(3.37 \mathrm{t} / \mathrm{ha}^{-1}\right)$. The widest root diameter, longest root length, the highest root weight, total soluble solids content, total sugar content, antioxidant activity were determined in different doses of poultry manure applications. A correlation between the examined quality and plant characteristics was determined. The other the most dry matter $(11.80 \%)$, phenolic matter (188.98 mg. $10-^{2}$ microgram $/ g$ GAE) and b carotene $\left(205.95 \mathrm{mg}^{-\mathrm{g}^{-1}}\right)$ contents was determined in conventional application. The different doses poultry manure application on growth and yield of carrot were determined a positive effect.

\section{Effect of integrated sources of nutrients on growth and yield of vegetable crops}

\section{Onion}

Singh et al., (1997) investigated the effects of different organic manures and inorganic fertilizers on the yield and quality of Rabi onion (cv. Agrifound Light Red). The findings revealed that farmyard manure produced the highest gross and marketable yields of onion. The similar findings had been observed by Yadav and Yadav, (2001) who reported that the recommended FYM + NPK significantly produced highest bulb yield (370.39 $\mathrm{q} \mathrm{ha}^{-1}$ ). Another study carried out by Alkaff et al., (2002) who obtained the larger size bulb (44 $\%)$ with mineral fertilizer, followed by, the biofertilizer and FYM. The highest yield/ha ${ }^{-1}$ $(21.76 \%)$ was recorded with FYM, followed by, the mineral fertilizer and biofertilizer. Reddy and Reddy, (2005) studied the effect of different levels of vermicompost $(0,10,20$ and $30 \mathrm{t} \mathrm{ha}^{-1}$ ) on growth of onion (cv. N-53). The results revealed that treatment containing vermicompost from 10 to $30 \mathrm{t} \mathrm{ha}^{-1}$ significantly increased plant height, number of leaves per plant and leaf area. Patil et al., (2005) assessed the effect of flyash and FYM 
on nutrient uptake and yield of onion. The results indicated that with increasing levels of FYM $\left(0,5,15\right.$ and $\left.30 \mathrm{t} \mathrm{ha}^{-1}\right)$, significantly increases the uptake of $\mathrm{N}$ (ranging from 0.08 to $0.13 \mathrm{~g} / \mathrm{plant}$ ), $\mathrm{P}$ (ranging from 0.12 to 0.15 $\mathrm{g} /$ plant) and $\mathrm{K}$ (ranging from 0.61 to 0.92 $\mathrm{g} /$ plant) by onion bulb besides increasing onion yield. Jayathilake et al., (2006) reported that the application of vermicompost alone had significantly produced higher bulb yield $\left(18.8 \mathrm{tha}^{-1}\right)$ than the sole application of FYM or combined application of FYM and vermicompost. An experiment carried out by Dimri and Singh, (2006) to assess the effect of FYM on onion bulb yield. The results indicated that application of FYM @ $15 \mathrm{t} \mathrm{ha}^{-1}$ produced the highest bulb weight, i.e. $74.45 \mathrm{~g}$ with the total onion yield of $291.02 \mathrm{q} \mathrm{ha}^{-1}$. Similar results were observed by Lal and Khurana, (2007) who reported that application of FYM @ $20 \mathrm{t} \mathrm{ha}^{-1}$ increased the onion bulb yield as compared than RDF in potato-onionguar sequence rotation. The results were close conformity with the results of Ansari, (2008) who investigated the effect of vermicompost and vermiwash in reclaimed sodic soils on the productivity of onion. The findings revealed that the yield of onion was significantly higher in plots treated with vermiwash $(1: 10 \mathrm{v} / \mathrm{v}$ in water), whereas the average weight of onion bulbs was significantly greater in plots amended with vermicompost and vermiwash (1:5 v/v in water). Yeptho et al., (2009) observed maximum P content in leaf $(0.34 \%)$ and bulb $(0.46 \%)$ when plants were treated with Vermicompost + Azotobacter. Prabhakar et al., (2012) evaluated the growth and yield of onion treated by organic manure and inorganic nutrients. The treatment received $100 \%$ recommended $\mathrm{N}$, equivalent through organics produced the highest yield of $21.06 \mathrm{t}$ $\mathrm{ha}^{-1}$, plant height and leaf area index. However, Lee, (2012) found that the application of cattle manure compost improved yield of intermediate-day onion and soil fertility under reduced rates of chemical fertilizer. The results also demonstrated that CMC (cattle manure compost) application over $40 \mathrm{Mg} \mathrm{ha}^{-1}\left(1 \mathrm{Mg} \mathrm{ha}^{-1}=0.4461 \mathrm{t} \mathrm{acre}^{-1}\right)$ did not exhibit the effect in onion bulb yield but accumulated soil nutrients in the plants. Kaswan et al., (2013) had the maximum number of leaves per plant, plant height, fresh weight of bulb, diameter of bulb, volume of bulb, bulb yield, TSS and pungency with the application of FYM @ $40 \mathrm{t} \mathrm{ha}^{-1}$. In the field trial conducted by Gopakkali and Sharanappa, (2014) to study the effect of different organic treatments on growth and yield of onion. The findings exhibited that the application of enriched bio-digested liquid manure (EBDLM)@ $100 \mathrm{~kg} \mathrm{~N}$ equivalent/ha + 3 sprays of panchagavya (3\%) recorded the highest plant height $(42.3 \mathrm{~cm})$, leaves/plant (8.1), leaf diameter $(1.46 \mathrm{~cm})$, fresh weight of bulb (143.7 g), bulb yield (42.8 $\left.\mathrm{t} \mathrm{ha}^{-1}\right)$, neck diameter $(1.42 \mathrm{~cm})$, bulb diameter $(6.02 \mathrm{~cm})$, bulb length $(5.36 \mathrm{~cm})$, total soluble solids $\left(14.4{ }^{\circ} \mathrm{B}\right)$. Moradi, (2015) observed that the application of sheep manure $\left(5 \mathrm{t} \mathrm{ha}^{-1}\right)$ increased fresh weight, dry weight, plant volume, bulb diameter, bulb height and plant height as compared to control. Talwar et al., (2016) assessed the effect of different combinations of bio-fertilizer along with inorganic fertilizers and organic manures on growth, yield and quality of onion during kharif season. The results revealed that the number of leaves per plant, plant height and leaf area was maximum with the application of Azotobacter along with recommended dose of fertilizers. Minimum neck thickness was recorded in treatment where Azospirillium was applied along with recommended dose of fertilizers. Likewise, the Azospirillum produced the maximum bulb weight $138.3 \mathrm{~g}$ and total yield $299.6 \mathrm{q} / \mathrm{ha}$ when it was applied with recommended dose of fertilizer. However, maximum bulb diameter was recorded when plants were treated with Azotobacter along with recommended dose of fertilizers. Prabhakar et al., (2017) studied the 
effect of different levels of farm yard manure (FYM) in organic as compared to chemical and conventional practices on growth, yield and quality of onion. The findings indicated that the plants received organic manure equivalent to 100 per cent recommended dose of nitrogen (RDN) had highest number of leaves (10.5) per plant. The bulb yield was on par with the yields obtained in organic treatments receiving FYM equivalent to 50 to 100 per cent RDN. The lower bulb yields were observed with organic treatment receiving manures equivalent to 25 per cent RDN and treatment receiving only NPK fertilizers. Singh et al., (2018) evaluated the effect of organic farming on yield, yield parameters and storage quality of onion (Allium cepa L.) in Rabi season. The results exhibited that the treatment contains, RDF + organic source gave maximum total bulb yield $(258.38 \mathrm{q} / \mathrm{ha})$ followed by, vermicompost @ 15 t/ha and by Farm Yard Manure @ 30 /ha with (237.38 $\mathrm{q} / \mathrm{ha}$ ) and (222.65 q/ha) respectively. In case of marketable bulb yield, the plants treated by INM (RDF + organic source) followed by, Vermicompost @ 15 t/ha gave maximum marketable bulb yield $(250.02 \mathrm{q} / \mathrm{ha})$ and (230.01 q/ha) respectively. Maximum cost benefit ratio was found in the treatment, treated by RDF + organic source followed by, Vermicompost@15 t/ha with (2.61: 1) and (2.34: 1) respectively. Minimum total storage losses were recorded when plants were received Vermicompost @ 15 t/ha with (71.25 $\%$ ) which was best from rest treatments during investigation. However, maximum dry matter yield gave by Poultry manure @ 15 t/ha.

\section{Cabbage}

Kanwar and Paliyal, (2005) observed a net saving of $50 \%$ of synthetic fertilizer by substituting vermicompost for FYM along with $100 \%$ NPK. Kumar et al., (2008) analyzed the different integrated nutrient managements on the growth parameters in cabbage (Brassica oleracea L.var. Capitata). The findings revealed that the treatment consisting $80 \mathrm{~kg} \mathrm{~N}+80 \mathrm{~kg} \mathrm{P}_{2} \mathrm{O}_{5}+60 \mathrm{~kg} \mathrm{~K}_{2} \mathrm{O}$ $+20 \mathrm{~kg} \mathrm{ZnSO} 4+\mathrm{VC} 5 \mathrm{t} /$ ha followed by 100 $\mathrm{kg} \mathrm{N}+80 \mathrm{~kg} \mathrm{P}_{2} \mathrm{O}_{5}+60 \mathrm{~kg} \mathrm{~K}_{2} \mathrm{O}+20 \mathrm{~kg}$ $\mathrm{ZnSO}_{4}+\mathrm{FYM} 10 \mathrm{t} / \mathrm{ha}$ as the best in respect to higher values for growth attributing parameters in cabbage. Similar findings were observed by Devi and Roy, (2008) who conducted an experiment to study the effect of different integrated combinations on growth and economic yield of cabbage. The integrated treatment consisting $120 \mathrm{~N}, 100 \mathrm{P}$ and $120 \mathrm{~K}$ $\mathrm{kg} / \mathrm{ha}+25 \mathrm{t} \mathrm{FYM} / \mathrm{ha}+$ Azotobacter $2 \mathrm{~kg} / \mathrm{ha}+$ Phosphotika $2 \mathrm{Kg} / \mathrm{ha}$ recorded maximum of yielding parameters like diameter $(15.37 \mathrm{~cm}$ and $14.69 \mathrm{~cm}$ for polar diameter and equatorial diameter, respectively) and consequently the yield (34.11 t/ha) and net profit as well. As application of $60 \mathrm{~N}, 100 \mathrm{P}$, $120 \mathrm{~K} \mathrm{~kg} / \mathrm{ha}+25 \mathrm{t} \mathrm{FYM} / \mathrm{ha}+$ Azotobacter 2 $\mathrm{kg} / \mathrm{ha}+$ Phosphotika $2 \mathrm{~kg} / \mathrm{ha}$ yielded at par with N $120 \mathrm{~kg} / \mathrm{ha}, \mathrm{P} 100 \mathrm{~kg} / \mathrm{ha}, \mathrm{K} 120 \mathrm{~kg} / \mathrm{ha}+$ $25 \mathrm{t}$ FYM/ha (without biofertilizers). It showed that biofertilizers could result in a net saving of $50 \%$ of nitrogen. Sarangthem et al., (2011) obtained significantly highest yield of cabbage $(17.89$ t/ha) with the combined application of vermicompost @ 3 t/ha and Azospirillum vis-a-vis sole application of FYM @ 3 t/ha. The concentration of nutrients like (NPK) in shoot and root of cabbage were also higher in the treatment receiving vermicompost @ 3 t/ha along with Azospirillum as compared to FYM treatments. Chatterjee et al., (2012) revealed that cabbage head yield and its shelf life; TSS, vitamin A and vitamin $\mathrm{C}$ contents were significantly influenced by the application of organic manures and biofertilizers. Vermicompost which emerged as better organic sources of nutrient over farmyard manure. Inoculation with Azophos, a commercial biofertilizer preparation containing the Azotobacter and PSB exerted more positive result over uninoculated treatments and benefits of 
biofertilizer application were more in presence of vermicompost as compared to farmyard manure. However, Merentola et al., (2012) obtained the maximum head yield (56.37 t/ha) with $50 \% \mathrm{NPK}+50 \% \mathrm{FYM}+$ biofertilizers which was significantly superior over other treatments except $100 \%$ NPK, $50 \%$ NPK+50 $\%$ Pig manure + biofertilizers and $50 \%$ NPK $+50 \%$ vermicompost + biofertilizers, where values of head yield were $49.38 \mathrm{t} / \mathrm{ha}, 50.56$ t/ha and 53.64 t/ha, respectively. Singh et al., (2015) concluded that combined application of NPK @ 200:100:100 Kg/ha along with seedling treated with Azospirillum gave significantly higher plant height $(30.40 \mathrm{~cm})$, plant spread $(54.50 \mathrm{~cm})$, head diameter $(24.32 \mathrm{~cm})$, head depth $(21.71 \mathrm{~cm})$, head weight $(1.878 \mathrm{Kg})$ and head yield (868.70 q/ha) while, days taken to head formation and head maturity, number of outer leaves/plant and number of inner leaves/head did not show significant interaction effects. Jha et al., (2017) studied the effect of organic, inrganic \& biofertilizers on growth attributes of cabbage (Brassica oleracea var. Capitata).

The results showed that maximum head formation was recorded $(95.01 \%)$ with $75 \%$ $\mathrm{RDF}+25 \% \mathrm{~N}$ through FYM and the treatment consisting $\mathrm{FYM}+\mathrm{VC}+\mathrm{AZ}+\mathrm{PSB}$ had $(78.41 \%)$ at harvesting stage. Maximum head height was recorded 60 DAT and time of harvest are $16.91 \mathrm{~cm}$ and $20.79 \mathrm{~cm}$ under treatment $75 \% \mathrm{RDF}+25 \% \mathrm{~N}$ through FYM, while minimum head height was recorded $12.43 \mathrm{~cm}$ and $14.71 \mathrm{~cm}$ under treatment $75 \%$ $\mathrm{RDF}+25 \% \mathrm{~N}$ through $\mathrm{VC}$ and $100 \% \mathrm{RDF}+$ $25 \% \mathrm{~N}$ through FYM. Maximum head diameter was recorded 60 DAT and time of harvest are $42.65 \mathrm{~cm}$ and $46.37 \mathrm{~cm}$ under treatment $75 \%$ RDF $+25 \% \mathrm{~N}$ through FYM minimum head diameter was recorded 24.90 $\mathrm{cm}$ and $32.69 \mathrm{~cm}$ under treatment $100 \%$ RDF $+25 \% \mathrm{~N}$ through $\mathrm{VC}$ and $50 \% \mathrm{RDF}+50 \%$ $\mathrm{N}$ through FYM.

\section{Tomato}

Balasubramanian et al., (1998) assessed the effect of organic and inorganic nutrients on the yield and uptake of tomato (Lycopersicon esculentum) in Alfisols. The findings showed that organic and inorganic nutrients in combined form recorded the highest tomato yield, dry matter production content and uptake of nutrients and the residual soil fertility. An experiment conducted by Natarajan et al., (2004) to assess the effect of organic and inorganic fertilizers on growth and yield of tomato. Integrated treatment consisting of 50 per cent RDF (100:50:50 NPK kg ha-1) per cent + FYM $12.5 \mathrm{t} \mathrm{ha}^{-1}$ resulted in highest vegetative growth and yield (586.51 q ha $\mathrm{q}^{-1}$. Similar findings were also reported by Madalageri et al., (2006) who had reported that treatment receiving RDF (115:100:60 kg NPK ha ${ }^{-1}$ ) along with FYM 25 $\mathrm{t} \mathrm{ha}^{-1}$ recorded higher keeping quality (18.5 days) of tomato cv. Megha at room temperature. However, Sudhakar and Purushotham, (2008) concluded that application of 75 per cent RDF (150:60:80 NPK kg ha ${ }^{-1}$ ) and bio-fertilizer PSB (15 kg $\mathrm{ha}^{-1}$ ) resulted in higher yield parameter like number of fruits per plant $(25.75 \mathrm{~g})$, yield per plant $(751.8 \mathrm{~kg})$ and yield $\left(75.10 \mathrm{t} \mathrm{ha}^{-1}\right)$ of tomato. Similarly, Mahato et al., (2009) recorded maximum shoot length $(35.5 \mathrm{~cm})$, number of leaves per plant (5.6), root length $(7.8 \mathrm{~cm})$ with Azatobactor $\left(2 \mathrm{~kg} \mathrm{ha}^{-1}\right)$ along with 50 per cent $\operatorname{RDF}$ (150:50:50 $\mathrm{kg} \mathrm{ha}^{-1}$ ) during the raising of seedlings in nursery in tomato as compared to other treatments. While, Premshekhar and Rajashree, (2009) found the maximum plant height $(72.60 \mathrm{~cm})$, number of fruits per plant (33.70) and fruit yield (43.85 $\left.\mathrm{t} \mathrm{ha}^{-1}\right)$ with application with Azospirillum $\left(2 \mathrm{~kg} \mathrm{ha}^{-1}\right)+75$ per cent Nitrogen +100 per cent $\mathrm{P}$ and $\mathrm{K}$ as compared to other treatments in tomato. Prabhu et al., (2010) studied the effect of organic fertilizer on rhizosphere, growth and yield of tomato. The 
findings revealed that application of RDF (120:60:60 kg ha ${ }^{-1}$ ) along with vermicompost $\left(5 \mathrm{tha}^{-1}\right)$ produced maximum growth and yield parameters like plant height $(88.0 \mathrm{~cm})$, fruit weight $(65.8 \mathrm{~g})$, fruit yield per ha $\left(60.68 \mathrm{t} \mathrm{ha}^{-1}\right)$ in tomato. However, Sharma et al., (2010) reported that the combined application of seedling dip with Azotobactor $2 \mathrm{~kg} \mathrm{ha}^{-1}+75$ per cent $\mathrm{N}+$ full dose of PK + full dose of FYM (25 t ha $\left.{ }^{-1}\right)$ significantly increased growth, yield and quality characters over RDF or organic manures alone there by a saving of 25 per cent chemical nitrogen application during the year of study. The same treatment also found superior in terms of maximum net returns Rs. 1, 48, 089/- and highest cost: benefit ratio of 1:2.51 in tomato. Another experiment carried out by Yeptho et al., (2010) who reported that integrated application of 50 per cent NPK +50 per cent poultry manure + bio-fertilizer gave maximum plant height $(164.33 \mathrm{~cm})$, number of branches per plant (12.26), number of laves per plant (58.19), number of fruits per plant (33.27), fruit yield (77.54 $\left.\mathrm{t} \mathrm{ha}^{-1}\right)$ and TSS content (6.67 ${ }^{\circ}$ Brix) over the other treatments in tomato. While, Prativa and Bhattarai, (2011) observed maximum plant height and number of leaves per plant with integrated treatment consisting $16.66 \mathrm{tha}^{-1} \mathrm{FYM}+8.33 \mathrm{tha}^{-1}$ vermicompost + NPK. The highest number of fruit clusters, maximum fruit weight and fruit yield $\left(25.74 \mathrm{mt} \mathrm{ha}^{-1}\right)$ were also recorded in the same treatment in tomato crop. Abul et al., (2012) checked the effect of Trichoderma-enriched bio-fertilizer for enhance the production and nutritional quality of tomato (Lycopersicum esculentum L.) and minimizes NPK fertilizer. The findings reported that application of Trichoderma $2 \mathrm{~kg} \mathrm{ha}^{-1}$ and RDF (100:50:60 kg $\mathrm{ha}^{-1}$ ) had maximum flowers per cluster (9.86), number of fruits per plant (25.66), maximum fruit weight $(64.35 \mathrm{~g})$ and yield per ha $(56.30 \mathrm{t}$ $\left.\mathrm{ha}^{-1}\right)$ as compared to control $(100: 50: 60 \mathrm{~kg}$ $\mathrm{ha}^{-1}$ ) while, all yield parameters were found minimum under control in tomato. Similar findings were also reported by (Manjural et al., 2012) who reported that application of 50 per cent nitrogen along with 50 per cent Trichoderma enriched bio-fertilizer showed higher plant height $(71.17 \mathrm{~cm})$, number of branches per plant (8.025), leaf area (69.73 $\mathrm{cm} 2$ ), number of clusters per plant (7.15), number of fruits per plant (41.03), fruit yield per plant (1.41 kg per plant) and fruit yield per hectare (156.36 q ha ${ }^{-1}$ ) in tomato crop. Kumar et al., (2014) reported that application of PSB at $2 \mathrm{~kg} \mathrm{ha}^{-1}$ results in maximum plant height $(39.50 \mathrm{~cm})$, higher number of branches per plant (6.93) and number of cluster per plant (9.83) as compared to Azospirillum $2 \mathrm{~kg} \mathrm{ha}^{-1}$ while, all growth parameters were found minimum under control in tomato. Singh et al., (2014) conducted an experiment to evaluate the effect of different combinations of organic manure and chemical fertilizers on growth of tomato. The findings reported that integrated treatment consisting 50 per cent $\mathrm{N}$ from inorganic sources +50 per cent $\mathrm{N}$ from FYM gave the maximum yield $\left(21.5 \mathrm{t} \mathrm{ha}^{-1}\right)$ and its contributing characters such as number of yield per plant $(1.93 \mathrm{~kg} / \mathrm{plant})$, fresh and dry weight of fruit $(177.07 \mathrm{~g} /$ fruit) followed by 100 per cent from inorganic source. Avhad et al., (2016) conducted a study to determine the influence of organic and inorganic fertilizers on growth yield and quality parameters of tomato hybrid Phule Raja. The results revealed that there was significant influence of combined use of organic and inorganic fertilizers on growth parameters, yield contributing characters and nutrient uptake. The integrated application containing RDF 300: 150:150 kg NPK and $20 \mathrm{t}$ FYM $\mathrm{ha}^{-1}$ ) gave highest value of plant height $(147.00 \mathrm{~cm})$, number of fruits per plant $(42.62)$ and average weight of fruit $(86.33 \mathrm{~g})$ yield per plant $(2.54 \mathrm{~kg} / \mathrm{pl})$. Islam et al., (2017) concluded that integrated plant nutrient system (IPNS) or mixed fertilizers containing (organic $2 / 3+$ inorganic $1 / 3$ ) produced higher number of fruits per plant (73.7) and plant 
height $(73.5 \mathrm{~cm})$. The results also demonstrated that fruit yield and diameter were found statistically significant. No significant difference was observed in the quality (total soluble solids) of tomato fruits in both varieties' response to the treatments. The electrical conductivity and $\mathrm{pH}$ of the soil were improved by the application of organic manure. Kumari and Tripathi, (2018) conducted an experiment to assess the influence of integrated nutrient management on yield and uptake of tomato (Solanum Lycopersicum L.) and availability of nutrients in soil under mid hill conditions. The results indicated that integrated treatment consisting $80 \% \mathrm{NPKM}+20 \% \mathrm{~N}$ through FYM and VC (50:50) + PGPR had significantly the highest uptake of N (97.81 kg/ha), P (25.08 kg/ha), K $(55.94 \mathrm{~kg} / \mathrm{ha})$. Fruit yield $(606.51 \mathrm{q} / \mathrm{ha})$ of tomato were also highest in $80 \%$ NPKM + $20 \% \mathrm{~N}$ through FYM and VC (50:50) + PGPR whereas, interaction effect between treatment and year $(\mathrm{T} \times \mathrm{Y})$ revealed a non-significant effect, while treatment (T) showed significant effect under tomato crop. The highest available N (404.50 kg/ha) P (91.07 kg/ha) K $(285.38 \mathrm{~kg} / \mathrm{ha})$ was observed under $130 \%$ NPKM (50:50 of FYM and VC as per $\mathrm{N}$ content).

\section{Okra}

Prabhu et al., (2002) studied the effect of integrated nutrient management on fruit yield of okra. The results indicated that treatment consisting 75\% NPK+FYM+ Azospirillum + VAM produced the highest yield. Similar findings were also observed by Tripathy et al., (2004) who reported that the integrated application of $75 \%$ recommended dose of fertilizer $\quad(90: 60: 40 \quad \mathrm{~kg} \quad \mathrm{NPK} / \mathrm{Ha}) \quad+$ Vermicompost at $5 \mathrm{t} / \mathrm{Ha}$ significantly gave higher marketable fruit yield $(91.75 \mathrm{q} / \mathrm{Ha})$ over the control and other treatments. Ray et al., (2005) reported that the application of Azospirillum or Azotobacter supplemented with $15 \mathrm{t}$ FYM/Ha and 25:15.5:12.5 kg/ha NPK in okra was more beneficial for sustaining higher growth and yield of crop and promoting inherent fertility status of soil in medium land of Dankuni basin. However, Prabhu et al., (2006) concluded that the combination of full RDF at 100:50:50 NPK $\mathrm{kg} / \mathrm{ha}+\mathrm{FYM}$ at $10 \mathrm{t} / \mathrm{Ha}+$ Azospirillum + VAM gave the maximum seed yield and seed qualities in okra. Tripathy et al., (2008) examined the effect of integrated nutrient management on survivability of different diseases and fruit yield in okra. The findings reported that application of $50 \% \mathrm{RDF}+\mathrm{BF}+$ organic manure in the form of neem cake or vermicompost significantly reduced jassid (4.02 - 4.50 / 3 leaves) YVMV (11.70 $13.09 \%)$ and furit borer $(5.53-6.13 \%)$ and recorded higher fruit yields of 83.03 to 85.51 q/ha. Bairwa et al., (2009) observed that application of $60 \%$ recommended dose of NPK through inorganic fertilizer + neem cake at 0.6 tonne/ha + Vermicompost at 1 tonn/Ha + Azotobacter + PSB resulted in significantly maximum plant height at 90 DAS $(77.80 \mathrm{~cm})$, stem base diameter $(2.25 \mathrm{~cm})$, total fruit bearing nodes/plant (19.18), number of fruit (18.36/plant), fruit weight (17.65 g), length of fruits $(12.26 \mathrm{~cm})$. The results also demonstrated that the same treatment was also found superior in terms of fruit yield increased $(29.30 \%)$ along with highest B: C ratio (3.19) while, Tripathy and Maity, (2009) observed that the application of $50 \% \mathrm{RDF}+\mathrm{BF}+$ organic manure in the form of neem cake @ $1.25 \mathrm{t} / \mathrm{ha}$ or vermicompost @ $2.5 \mathrm{t} / \mathrm{ha}$ significantly not only increased per plant yield $(408.54 \mathrm{~g})$ but also quality of fruit. Kumar et al., (2013) studied the integrated effect on growth and yield of okra. The findings revealed that the plant received $75 \mathrm{~kg} \mathrm{~N}+40 \mathrm{~kg}$ $\mathrm{P}_{2} \mathrm{O}_{5}+40 \mathrm{~kg} \mathrm{~K} \mathrm{~K}_{2} \mathrm{O}+5$ tones $\mathrm{VC}+20 \mathrm{Kg}$ $\mathrm{ZnSo} 4 /$ ha gave the maximum growth and yield. The same treatment was also found superior in terms of gross income Rs. (58600), net return Rs. (25677) and cost: benefit ratio. 
Similar findings were also reported by Ghuge et al., (2015) who stated that integrated treatment consisting 75\% NPK+ FYM+PSB + Azotobacter produced maximum plant height $(118.17 \mathrm{~cm})$, number of leaves (36.6), number of internodes (16.9), length of 2nd internode $(112.7 \mathrm{~cm})$, germination percentage $(88.37 \%)$, dry fruits per plant (17.73), seed yield (9.7 $\mathrm{q} / \mathrm{ha})$, length of dry fruit per plant $(16.93 \mathrm{~cm})$, diameter of dry fruit $(18.33 \mathrm{~mm}), 1000$ seed weight $(26.63 \mathrm{~g})$, weight of seed per plant $(77.84 \mathrm{~g})$ and minimum day's for fruit maturity (87.27 days). The maximum stem diameter $(19.27 \mathrm{~mm})$ was recorded with application of $125 \%$ NPK. The minimum days required for flower bud initiation (34.47days), flower opening (36.4 days), fruit initiation (37.33 days) were recorded with the application of $100 \%$ NPK. However, maximum number of branches (3.2) and graded seed percentage $(97.85 \%)$ were recorded with $50 \%$ NPK+ FYM + PSB + Azotobacter. Choudhary et al., (2015) assessed the impact of bio-fertilizers and chemical fertilizers on growth and yield of okra (Abelmoschus esculentus L. Moench). The findings demonstrated that the integrated treatment receiving Azospirillum $5 \mathrm{~kg} \mathrm{ha}^{-1}+$ RD NPK significantly produced maximum plant height $(96.03 \mathrm{~cm})$, pod weight $(11.53 \mathrm{~g})$, girth of pod $(4.88 \mathrm{~cm})$, yield plant ${ }^{-1}(139.39 \mathrm{~g})$ and yield $\mathrm{ha}^{-1}(10324.94 \mathrm{~kg})$. The plants treated with PSB $5 \mathrm{~kg} \mathrm{ha}^{-1}+$ RD NPK through chemical fertilizers had the highest length of pod $(12.03 \mathrm{~cm})$. Whereas, the plants treated with VAM $15 \mathrm{~kg} \mathrm{ha}^{-1}+75 \% \mathrm{P}+100 \% \mathrm{NK}$ through chemical fertilizers had the highest number of pods per plant (13.11). Sachan et al., (2017) evaluated the growth, yield and quality of okra (Abelmoschus esculentus L.) as influenced by the integrated nutrient management. The results revealed that the plants treated with NPK @ 75\% + FYM $@ 2.5 \mathrm{tn} / \mathrm{ha}+$ Poultry manure @2.5tn/ha + Vermi- compost @2.5tn/ha significantly found best among the all treatments at all successive growth stages in almost all the traits i.e. plant height $(154.0 \mathrm{~cm})$, number of branches per plant (4.91), fresh weight of plant (17.11t/ha) and dry weight of plant $(2267.67 \mathrm{~kg} / \mathrm{ha})$ as growth parameters; whereas no. of pods per plant (12.44), single pod weight $(15.17 \mathrm{gm})$, length of pods $(11.58 \mathrm{~cm})$, dry weight of pods $(1039.33 \mathrm{~kg} / \mathrm{ha})$, total pod yield $(14.29 \mathrm{t} / \mathrm{ha})$ as yield related traits.

\section{Brinjal}

Anburani and Manivannan, (2002) assessed the effect of integrated nutrient management on growth in brinjal (Solanum melongena L.) cv. Annamalai. The results indicated that the treatment consisting FYM + Press mud $12.5 \mathrm{t}$ $\mathrm{ha}^{-1}$ each along with 100 per cent NPK + biofertilizers had the highest plant height (108.90 $\mathrm{cm}$ ), number of primary branches (11.66) and number of leaves (94.05) whereas, FYM at 25 t ha ${ }^{-1}$ along with 100 per cent NPK + biofertilizers (Azospirillum + PSB) recorded the highest stem girth $(3.71 \mathrm{~cm})$, number of secondary branches (15.58) in brinjal. However, Ullah et al., (2008) observed the maximum number of fruits, maximum length of fruits and maximum fruit diameter and maximum fruit weight when plants were treated with $20 \%$ cowdung $+20 \%$ mustard oilcake $+20 \%$ poultry manure $+40 \%$ NPK fertilizers. Kumar and Gowda, (2010) conducted an experiment on effect of different organic manures and inorganic fertilizers on growth and yield of brinjal (Solanum melongena L.). Application of recommended $25 \mathrm{t} /$ ha of FYM, N through vermicompost and green manure $(50 \%$ each) + recommended NPK (125:100:50 kg/ha) recorded maximum plant height, number of leaves and total dry matter of plant. The number of branches was highest with the treatment of $150 \%$ recommended FYM only, earliness for first $50 \%$ flowering and first harvest was observed with $100 \%$ recommended FYM alone. Christo et al., (2011) found higher fruit yield 
$(4,076 \mathrm{~kg} / \mathrm{ha})$ and number of fruit per plant (79.0) with application of $7500 \mathrm{~kg} / \mathrm{ha}$ include with pig slurry, but application of $5000 \mathrm{~kg} / \mathrm{ha}$ of poultry droppings gave the highest leaf yield. However, Vijay and Seethalakshmi, (2011) revealed that the application of Vermicompost made from Parthenium @5 t/ha + 50\% RDF) gave maximum height of plant while, maximum fruit weight was recorded with (PartheniumVermicompost2.5 t/ ha+FYM @6.25 t/ha). Suge et al., (2011) conducted an experiment to evaluate the effect of combination between two levels of recommended dose of mineral fertilizers. The application of farmyard manure had significantly highest plant height of $58 \mathrm{~cm}$ and $64.5 \mathrm{~cm}$ and fresh weight of $370.67 \mathrm{~g}$ and $407.67 \mathrm{~g}$ as compared to other organic sources of manures and their control respectively in 2009 SRS.

During 2010 in LRS similar trend was observed with plant height of $57.3 \mathrm{~cm}$ and 62 $\mathrm{cm}$ for FYM compared to $39 \mathrm{~cm}$ and $42.33 \mathrm{~cm}$ for control respectively. However, Suchitra and Manivannan, (2012) found that the application of vermicompost @ 5t/ha and Humic Acid $0.2 \%$ had the number of fruits plant $^{-1}(30.11)$, length of fruit $(14.30 \mathrm{~cm})$ and girth of fruit $(13.75 \mathrm{~cm})$. Mujawar, (2012) carried out an experiment to assess the effect of organic and inorganic sources of nutrients on yield of brinjal. The results indicated that the treatment containing RDF+FYM recorded significantly higher fruit yield (5.24 $\left.\mathrm{tha}^{-1}\right)$ and it was on par with RDF and organics and chemical fertilizers applied each at 50 per cent level either alone or with liquid organics. Munshi, (2014) revealed that the application of $32 \mathrm{~kg}$ compost $+50 \%$ NPK gave the greater yield over all treatments that was statistically similar to $32 \mathrm{~kg}$ of compost (21.61 MT/ha, 21.24 MT/ha) respectively. The lowest yield (9.63 MT/ha) was obtained from the plots amended with $16 \mathrm{~kg}$ of compost. There was statistically similarity in the average weight per fruit amongst the plots amended with 32 $\mathrm{kg}$ of compost, $32 \mathrm{~kg}$ of compost $+50 \% \mathrm{NPK}$ and $100 \%$ NPK (47.78 g, $48.61 \mathrm{~g}, 47.80 \mathrm{~g})$ respectively. Agrawal and Sharma, (2014) conducted a pot experiment to assess the impact of live earthworm + cattle dung (as feed), cow dung compost, vermicompost, chemical fertilizers and control (without fertilizer) on growth of brinjal (Solanum melongena $\mathrm{L}$.). The results indicated that the application of live earthworm + cattle dung had maximum plant height, fruit weight, time taken in budding and flowering, consecutively and number of in treated plants followed by, vermicompost treated plants and it was minimum observed in control. Kashyap et al., (2014) carried out an experiment to find the effect of different doses of organic manures and inorganic fertilizers on growth of brinjal var. Pant Rituraj. The result revealed that the treatment consists $25 \% \mathrm{RDF}+75 \%$ Neemcake produced maximum plant height, number of branches, number of leaves and maximum numbers of flowers were noted with $75 \% \mathrm{RDF}+25 \%$ Vermicompost, while, maximum fruit weight, fruit length, fruit diameter, number of fruits per plant observed under $25 \%$ RDF+75\% Neemcake. Najar et al., (2015) observed that different rates of vermicompost produced significant effect $(P<$ $0.05)$ as compared to the control on growth parameters with maximum value recorded at 6 $\mathrm{t} / \mathrm{ha}$, followed by $4 \mathrm{t} / \mathrm{ha}$ and the least at $2 \mathrm{t} / \mathrm{ha}$. Kumar, (2016) revealed that application of $50 \%$ RDF along with vermicompost @ 5 t/ha exhibited higher plant height and dry weight with in Brinjal. Zainub et al., (2016) conducted an experiment to evaluate the response of brinjal during 2014. Achieved higher number of fruits plant ${ }^{-1}$ (16.37), total yield $\left(13.72 \mathrm{t} \mathrm{ha}^{-1}\right)$ with nitrogen at $130 \mathrm{~kg} \mathrm{ha}^{-1}$ by integrated sources of nutrients. The similar findings were also observed by Barman et al., (2017) who reported that application of recommended dose of NPK 100:50:50 gave highest plant height $(73.71 \mathrm{~cm})$ followed by, 
$50 \%$ recommended dose of nitrogen through $\mathrm{FYM}+50 \%$ nitrogen through poultry manure.

\section{Potato}

Jaggi et al., (1995) studied the effect of FYM and phosphorus fertilizer on tuber yield of potato. The highest tuber yield was obtained with the application of 10 tonnes FYM with $60 \mathrm{~kg} \mathrm{P}_{2} \mathrm{O}_{5} \mathrm{ha}^{-1}$. An experiment conducted by Patil et al., (1997) to study the effect of vermicompost, FYM and inorganic fertilizers on growth, yield and uptake of nutrients in potato $c v$. Kufri Chandramukhi. The findings revealed that combination of VC@ $4 \mathrm{t} \mathrm{ha}^{-1}+$ 50 per cent RDF given maximum yield (34 t $\mathrm{ha}^{-1}$ ). While, Mrinal et al., (1998) reported that integrated application of $75 \%$ of the recommended NPK (120:100:100 kg NPK $\left.\mathrm{ha}^{-1}\right)+2.5 \mathrm{t}$ vermicompost produced highest marketable tuber yield. Similarly, Bhukta, (2000) revealed that the application of $10 \mathrm{t}$ FYM along with 150:80:100 kg NPK ha ${ }^{-1}$ produced maximum yield. The findings exhibited that absence of FYM, the application of $150 \mathrm{~kg} \mathrm{~N}, 100 \mathrm{~kg} \mathrm{~K} \mathrm{~K}_{2} \mathrm{O}$ and 40 $\mathrm{kg} \mathrm{P}_{2} \mathrm{O}_{5}$ blended with cowdung slurry $(2: 1)$ proved equally better to that of $150: 80: 100 \mathrm{~kg}$ NPK ha ${ }^{-1}$. Further, it had also been reported that 75:40:50 kg NPK ha ${ }^{-1}$ can be saved, if it is applied along with cowdung @ $7.5 \mathrm{t} \mathrm{ha}^{-1}$. Pervez et al., (2000) studied the effect of organic manure and inorganic fertilizers particularly for increased doses of potash on the yield and quality of potato. Various doses of potassium $\left(\mathrm{K}_{2} \mathrm{O}\right)$ i.e. $25,50,75,100,200$ and $300 \mathrm{~kg}$ mixed with combined application of five tons rottened FYM ha ${ }^{-1}$. Nitrogen and phosphorus were applied as a single constant dose i.e. $130 \mathrm{~kg}$ each $\mathrm{ha}^{-1}$ at the time of sowing and at the time of earthing up, respectively. Potash application alone did not show any promising results, although increased levels of potassium increased the yield to some extent. Combined application of FYM and higher doses of potassium proved best to increase the yield of potato. Santlal, (2003) studied that the effect of nitrogen in the form of urea and bulky organic manure on production of potato. The plants treated with $100 \%$ Urea $\mathrm{N}+250 \mathrm{q} \mathrm{ha}^{-1} \mathrm{FYM}$ attained maximum plant height, number of leaves per plant, number of tuber per plant, shoot weight (fresh and dry) per plant and tuber weight (fresh and dry) per plant and number of shoots per plant. Similar results were reported by Nag, (2006) who advocated that the growth parameters like plant height $(\mathrm{cm})$, number of shoots plant $^{-1}$, number of compound leaves plant $^{-1}$, number of tubers plant ${ }^{-1}$, fresh weight of shoots plant ${ }^{-1}$, fresh weight of tubers plant ${ }^{-1}$, dry weight of shoots plant ${ }^{-1}$ and dry weight of tubers plant $^{-1}$ were influenced with the increase in per cent of RDF. The highest value of all the above parameters was recorded under the treatment consisting 125\% RDF + organic manure (FYM) @ $20 \mathrm{t} \mathrm{ha}^{-1}$. Sood, (2007) reported that combined use of organic and inorganic fertilizers in the ratio of $1: 3$ significantly increased plant growth parameters, tuber yield and nutrient uptake. The higher tuber yield under integrated use of organic and inorganic fertilizers was mainly due to higher proportion of large and medium size tubers. While, Solanke et al., (2009) observed that the plants treated with $100 \%$ $\mathrm{RDF}+5 \mathrm{t}$ FYM ha ${ }^{-1}+$ Biofertilizers had maximized plant height $\left(54.9 \mathrm{~cm}\right.$ plant $\left.^{-1}\right)$, number of functional leaves (40.8 plant $^{-1}$ ), fresh weight of tubers $\left(285.6 \mathrm{~g} \mathrm{plant}^{-1}\right)$, total dry matter (69.7 $\mathrm{g}$ plant $^{-1}$ ) and tuber yield. Maximum net returns (Rs. $35749 \mathrm{ha}^{-1}$ ) and benefit: cost ratio (1.74) was also observed in the same treatment. Choudhary et al., (2010) observed that vermicompost doses @ 20 or 30 $\mathrm{t} \mathrm{ha}^{-1}$ as well as biofertilizers alone or in combination with vermicompost increased plant height. However, application of vermicompost @ $30 \mathrm{t} \mathrm{ha}^{-1}$ along with coinoculation of PSB and Azotobacter appeared to be the best treatment combination over other treatments to realize highest 
productivity, profitability as well as soil fertility in potato under organic production in North-Western Himalayas. While, Sarkar et al., (2011) assessed the positive effect of application of nutrients from organic and inorganic source and their combinations on plant height, dry matter production, number of shoots, number of tubers, tuber yield of potato and highest net return was obtained with $40 \%$ organic $+60 \%$ inorganic followed by, $50 \%$ organic $+50 \%$ inorganic than other treatments. Similarly, Yadu (2011) concluded that the growth parameters like plant height, number of leaves plant ${ }^{-1}$, fresh weight of shoots plant $^{-1}$ dry weight of shoots plant $^{-1}$, fresh weight of tubers plant ${ }^{-1}$ and dry weight of tubers plant ${ }^{-1}$ were influenced with the increase in the per cent of RDF.

Kumar (2012) conducted three years experiment to study the effect of integrated nutrient management on growth and economic yield of potato. The pooled data obtained from the study revealed that integrated application of $50 \%$ of recommended NPK through inorganic and $50 \%$ RDN through PM recorded significantly highest tuber yield (22.73 t/ha) followed by, $100 \%$ recommended NPK through inorganic (22.20 t/ha) which were $228 \%$ and $223 \%$ respectively and its lower value observed in control. Integrated application of inorganic and organic fertilizers and seed treatment with Azotobactor + PSB biofertilizers improved tuber yield, nutrient uptake, and gave higher return as compared to other treatment combinations. Chandrakar et al., (2013) revealed that the application of $75 \% \mathrm{~N}$ inorganic fertilizer $+25 \% \mathrm{~N}$ organic (Poultry manure) $+\mathrm{PSB}+$ Azotobactor produced significantly highest growth parameters, yield attributes (number of stolons plant $^{-1}$, number of tubers plant ${ }^{-1}$, fresh weight and dry weight of tubers, tuberization efficiency) and total tuber yield. Congera et al., (2013) assessed the effect of water management weed and integrated nutrient management on yield of potato. The findings revealed that the application of $50 \% \mathrm{RDF}+$ $50 \%$ FYM + Azotobacter + Phosphobacteria recorded maximum total dry matter production $(21.67 \%)$ Similarly, the maximum uptake of $\mathrm{N}\left(97.17 \mathrm{~kg} \mathrm{ha}^{-1}\right), \mathrm{P}\left(21.76 \mathrm{~kg} \mathrm{ha}^{-1}\right)$ and $\mathrm{K}\left(159.63 \mathrm{~kg} \mathrm{ha}^{-1}\right)$ was found with plants provided $50 \% \mathrm{RDF}+50 \% \mathrm{FYM}+$ Azotobacter + PSB. However, Baishya et al., (2013) observed that the application of $75 \%$ recommended dose of fertilizers (RDF) through chemical fertilizers along with $25 \%$ recommended dose of nitrogen (RDN) through farm yard manure (FYM) and/or $100 \%$ RDF through chemical fertilizers recorded higher values of the yield parameters and produced higher tuber yield (26.0 and $25.6 \mathrm{t} \mathrm{ha}^{-1}$ ) than other treatments. Sayed et al., (2014) observed the effect of organic fertilization alone or with bio-fertilization could replace mineral fertilization in potato production with no adverse effect on quantity or quality of potato tubers. The highest plant height, haulm fresh weight, number of main stems, leaves content of phosphorus and potassium and total and marketable yields obtained from potato plants treated with 35.7 $\mathrm{mt}$. ha ${ }^{-1}$ of compost at 90 days after planting, compared to the control. The results indicated that organic production of potato using 23.8 mt.ha ${ }^{-1}$ of compost could be alternative sources of nutrients to replace conventional production without significant reduction in yield and quality. Yadav and Shrivastava, (2015) studied that the effect of integrated nutrient management on production of seed tubers of potato (Solanum tuberosum L.) from true potato seed. Integrated use of synthetic fertilizers and organic manures showed the significant impact on growth and yield attributes of potato. Highest yield of tubers $\left(12.4 \mathrm{t} \mathrm{ha}^{-1}\right)$ were recorded with application of $75 \%$ RDF through fertilizers and 25\% RDN through FYM which was significantly superior over rest of treatments. 
Fig.1 The nutrient budgets between inputs and outputs, and the principles of INM method (Jat et al., 2015)

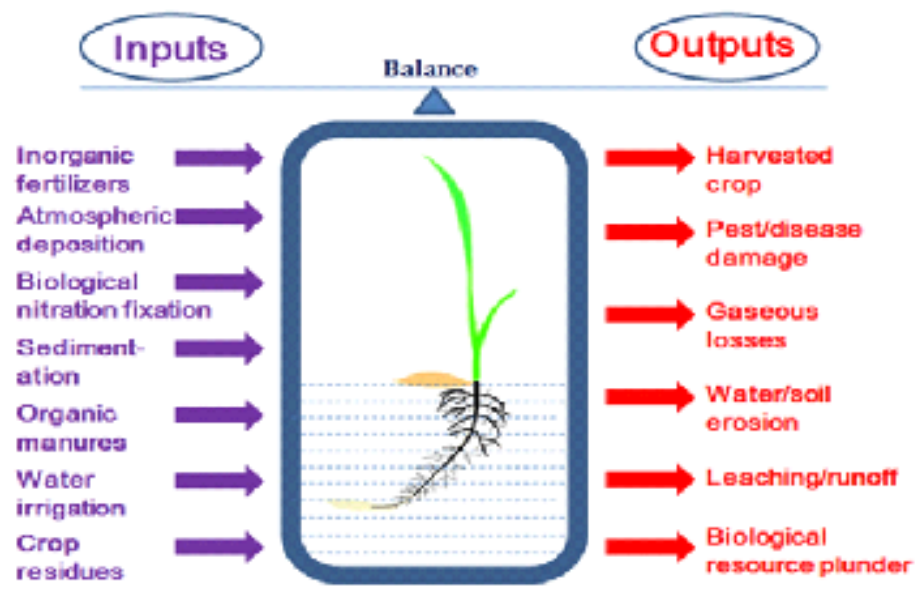

Singh et al., (2017) reported that the biofertilizers have stimulatory effect on germination, sprouting behaviour and growth parameter of potato. The maximum germination and number of bud tuber ${ }^{-1}$ with 5 in number was recorded with FYM @ 150g pot $^{-1}+$ Mustard cake@150g pot ${ }^{-1}+$ tuber treatment with $T$. viride + foliar spray with bio-formulation of $T$. viride. It was also mentioned in the study that bio-fertilizers have stimulatory effect on vigour of plants. The maximum plant height was recorded with soil application of mustard cake + tuber treatment and foliar spray with $T$. viride) with the value of $11.16 \mathrm{~cm}$ at 30 day age of plant. The effect of seed treatment and foliar spray with bio-fertilizer on tuber size and yield was recorded with the same treatment.

\section{Other vegetable crops}

Kale et al., (1991) reported that quantity of fertilization could be reduced by 25 to 30 per cent in radish, tomato, carrot and brinjal with application of vermicompost. However, Desai (1992) stated that application of one tonne vermicompost per hectare in capsicum resulted in slightly low yields as compared to chemical treatment plot while, net profit was more in vermiculture treated plots due to less cost of total inputs. Chattoo et al., (1997) studied the effect of biofertilizers and nitrogen on growth, yield and quality in Knol khol cv. Early White Vienna. Among the biofertilizers, Azosprillium proved better than Azotobacter in terms of better growth and yield of Knol khol. Increase in carrot yields was observed even with application of vermicompost (Ravindrababu, 1999). Reddy (2000) examined the effect of integrated nutrient management with vermicompost and nitrogenous fertilizer in onion (Allium cepa L.) - Radish (Raphanus savitus L.) cropping system for sustainable crop production. The results indicated that in radish the residual nutrients due to application of $30 \mathrm{t}$ vermicompost in onion resulted as significant increasement in bulb yield (42.03 $\left.\mathrm{t} \mathrm{ha}^{-1}\right)$. Shalini et al., (2002) assessed the combined effect of nitrogen with 50 and $75 \%$ of the recommended dose $(150 \mathrm{~kg} / \mathrm{ha})$ of nitrogen, organic manures (farmyard manure + vermicompost) with and without Azospirillium on yield of Knolkhol. The maximum plant height $(16.42 \mathrm{~cm})$, number of leaves $(19.42 \mathrm{~cm})$, dry matter production (35.41 g/plant) and maximum yield (37.21 $\mathrm{t} / \mathrm{ha}$ ) were recorded with $50 \%$ of $\mathrm{N}$ was sourced through inorganic and another $50 \%$ nitrogen through Vermicompost + 
Azospirillium. Available soil nitrogen was significantly higher in plots receiving organic manures and Azospirillum biofertilizer than those in inorganically fertilized plots. Prasad and Gaurav, (2004) noticed that the plants treated with Azospirillum along with Azotobacter gave highest yield (14.11 t/ha) in sprouting broccoli cv. Aishwarya. The application of organics viz., FYM, chilli stalks and FYM + chilli stalks with inorganic fertilizers (RDF) significantly influenced growth, yield nutrient uptake and quality of chilli and the magnitude of combined effect of organic and inorganic was higher than inorganic alone (Kattimani, 2004). However, Padamwar and Dakore (2009) found the application of vermicompost $(5 \mathrm{t} / \mathrm{ha})$ and Azotobacter $(10 \mathrm{~kg} / \mathrm{ha})$ to be most beneficial in increasing the yield and quality of cauliflower. Gupta et al., (2010) studied the role of INM on growth, vegetable yield and quality of Knol khol with bacterial inoculants (Azospirillum and Azotobacter). The findings revealed that all levels of nitrogen with both bacterial inoculants significantly increased in growth, yield and quality parameters as compared to control. However, better results were obtained by the application of $75 \%$ of chemical nitrogen along with both the inoculants thereby resulting a saving of $25 \%$ chemical nitrogen application. The results also demonstrated that the application of Azospirillum along with $75 \%$ chemical nitrogen proved better than Azotobacter. Sharma et al., (2012) investigated the response of cucumber, knol khol, broccoli and radish to the use of integrated nutrient management practices. The varieties used for study were Summer Green of cucumber, G-40 of Knol Khol, Early Green in case of Broccoli and CR-45 of Radish. Cucumber recorded highest yield of $213.85 \mathrm{q} / \mathrm{ha}$ with Neem Cake at $5 \mathrm{t} / \mathrm{ha}$. It was $17 \%$ superior to the recommended dose of chemical fertilizers. Yields were comparatively low with farm yard manure (FYM) vermicompost and poultry manure. Knol khol gave maximum yield with full dose of NPK + seedling treatment with Azatobactor at the time of transplanting with superiority of $45 \%$ over sole application of chemical fertilizers. Yields were reported low with organic treatments but FYM with seedling treatment with Azatobactor yielded satisfactorily to the level of $253.3 \mathrm{q} / \mathrm{ha}$. Broccoli responded well to INM treatment but yielded enough with FYM at $20 \mathrm{t} / \mathrm{ha}$ and poultry manure at $5 \mathrm{t} / \mathrm{ha}$ to justify its consideration of organic production. The results also demonstrated that vermicompost in combination with half dose of chemical fertilizers exhibited excellent in broccoli and radish. However, application of FYM and vermicompost alone were superior to the use of chemical fertilizers. A yield advantage of 12 and $4 \%$ was obtained over recommended dose of chemical fertilizers with their respective application. The investigations revealed that integrated use of nutrient source is superior in application to chemical fertilizers alone. Singh and Kumar, (2016) studied the effect of integrated nutrient management on growth, yield and nutrient uptake of clusterbean (Cyamopsis tetragonoloba). The results showed that application of 50, 75 and $100 \%$ of recommended dose of fertilizer $(20 \mathrm{~kg} \mathrm{~N}, 40$ $\mathrm{kg} \mathrm{P}_{2} \mathrm{O}_{5}$ /ha) gave 21.2, 45.7 and $50.8 \%$ higher yield over the control respectively. Association between Rhizobium and phosphate solublising bacteria was synergistic and inoculation of both fertilizers significantly improved the seed yield. Inoculation of Rhizobium, phosphate solublising bacteria and Rhizobium + phosphate solublising bacteria recorded 21.1, 14.1 and $24.7 \%$ higher seed yield than the control respectively. However, the combination of both inoculants further failed to significantly increase the seed and straw yield of clusterbean further. Mohanta et al., (2018) revealed that the application of $50 \%$ NPK + Vermicompost @2.5t/ha gave 
maximum values for plant height $(51.56 \mathrm{~cm})$, plant spread N-S $(61.63 \mathrm{~cm})$ and $\mathrm{E}-\mathrm{W}$ $(64.91 \mathrm{~cm})$, number of leaves per plant (22.27), leaf area $\left(405.45 \mathrm{~cm}^{2}\right)$, leaf length $(23.15 \mathrm{~cm})$, leaf width $(18.18 \mathrm{~cm})$, days to $50 \%$ head initiation (50.67days) and days to first harvest (51.00). The same treatment was also found superior in terms of highest head girth $(42.76 \mathrm{~cm})$, head diameter $(14.16 \mathrm{~cm})$, terminal head weight $(327.57 \mathrm{~g})$, head volume $(595.67 \mathrm{cc}), \quad$ gross yield $(233.56 \mathrm{q} / \mathrm{ha})$, marketable yield (163.63q/ha), vitamin C $(80.24 \mathrm{mg} / \mathrm{g})$, dry matter $(11.77 \%)$, gross returns (Rs.700680.00/ha), net returns (Rs. $525510.00 / \mathrm{ha}$ ) and benefit cost ratio (4.0).

In summary, the above findings clearly indicated that integrated sources of nutrients enhance the growth, yield, quality and soil fertility of vegetable crops as compared with control and recommended doses of inorganic fertilizers. This enhancement was appear due to proper and judious uses of inorganic and organic sources of nutrients which resulted in adequate supply of NPK and essential micronutrients on larger quantity to plants. A judicial combination of organics, in-organics and bio-fertilizers has been proved to give the best results on growth, yields, quality and soil fertility in vegetable crops.

The above results showed that the pure chemical or pure organic treatments could not improve yield, quality of vegetables as well as fertility of soils. The integration of organics and biofertilizers along with chemicals has a positive effect on above parameters and only gives highest net returns but also increases soil fertility status in harvested vegetable crops.

\section{References}

Abul, H., Amdadul, H., Manjurul, H. and Ilias, M. N. 2012. Trichodermaenriched bio-fertilizer enhances production and nutritional quality of tomato (Lycopersicum esculentum L.) and minimizes NPK fertilizer use. Agric. Res., 1(3): 265-272.

Adeleye, E.O., Ayeni, L.S. and Ojeniyi, S.O. 2010. Effect of poultry manure on soil physicochemical properties, leaf nutrient contents and yield of Yam (Dioscorea rotundata) on alfisol in South western Nigeria. Journal of American Science, 6(10): 871-878

Agarwal, S. and Sharma, J. 2014. Agronomic impact of earthworms, cow dung compost, vermicompost and chemical fertilizers on growth and yield of brinjal (Solanum melongena). Int. J. Environ. Eng. 6 (3): 249-260

Alkaff, H. A., Saeed, O. S. and Salim, A. Z. 2002. Effect of biofertilizer, inorganic, organic and foliar application of power 4 on the productivity of onion. University of Aden Journal Natural and Applied Science, 6 (1): 1-14

Anburani, A. and Manivannan, A. K. 2002. Effect of Integrated Nutrient Management on growth in brinjal (Solanum melongena L.) cv. Annamalai. South Indian Hort., 50 (46): $377-386$.

Ansari, A. A. 2008. Effect of vermicompost and vermiwash on the productivity of spinach (Spinacia oleracea), onion (Allium cepa L.) and potato (Solanum tuberosum). World Journal of Agricultural Sciences, 4 (5): 554-557

Avhad, A.B., Kshirsagar, D.B., Shinde, S.R. and Bhalekar, M.N. 2016. Effect of integrated nutrient management on growth, yield, quality and nutrient uptake in tomato. Asian Journal of Science and Technology, 7(4): 27312733

Azin, G. and Dhuma, K. N. 2012. Effect of organic manurer on growth, yield and quality of tomato. Green Farming, 3 (5): 557-559. 
Bahadur, A., Singh, J., Upadhyay, A. K. and Singh, K. P. 2003. Effect of organic manures and biofertilizers on growth, yield and quality attributes of broccoli (Brassica oleracea var. Italica plenck). Veg. Sci., 30(2): 192-194.

Bairwa, H.L., Mahawer, L.N., Shukla, A.K., Kaushik, R.A., Mathur S.R. 2009. Response of integrated nutrient management on growth, yield and quality of okra. Indian J. Agril. Sci., 79 (5): 381-384.

Baishya, L.K., Gupta, V.K., Lal, S.S., Das, B.K and Kumar, M. 2013. Effect of biofertilizers on growth and yield of potato in north eastern hills of India. Potato J., 32: 3-4.

Balasubramanian, P., Mani, A. K., Duraiswamu, P. and Kandaswamy, M. 1998. Effect of organic and inorganic nutrients on the yield and uptake of tomato (Lycopersicon esculentum) in Alfisols. South Indian Horticulture, 46 (3-4): 143-147.

Barman, K, S., Collis, J.P., Muralidharan, B. and Prasad, V.M. 2017. Effect of integrated nutrient management of plant brinjal (Solanum melongena). Int. J. Agri.. Sci. and Res., 7(1): 179-182.

Bhardwaj, S.K., Bhandari, A.R., Kaushal, R. and Singh, U. 2002. Response of integrated nutrient management and growth and yield of pea and cauliflower in mid hills. In: Annual convention of Indian Society of Soil Science held at JNKVV, Jabalpur during 10- 15 November, 2002.

Bhukta, M. 2000. Integrated use of cowdung slurry or FYM with inorganic fertilizer on soil fertility, growth, yield and nutrients uptake in potato. M.Sc. (Ag) Thesis, Indira Gandhi Krishi Vishwavidyala, Raipur, 80-82.

Ceronio, GM., Engelbrecht, G.M. and Mbatha, A.N. 2012. Organic fertilizer use and the potential influence on cabbage (Brassica oleracea L. var. capitata) plant and soil nutrient composition. Acta Horticulturae, 1 (938): 265-272

Chandrakar, C.K., Shrivastava, G.K., Chandrakar, A.K. and Dewangan, C. 2013. Effect of water management weed and integrated nutrient management on yield of potato (Solanum tuberosum). Trends in Biosci., 6 (5): 544-546.

Chatterjee, R., Jana, J.C. and Paul, P.K. 2012. Enhancement of head yield and quality of cabbage (Brassica oleracea) by combining different sources of nutrients. Indian Journal of Agricultural Sciences., 82: 324- 328.

Chatto, M.A., Gandroo, M.Y. and Zaragar, M.Y. 1997. Effect of Azospirillum and Azotobacter on growth, yield and quality of knol-khol (Brassica oleracea L. var. gongylodes). Vegetable Science, 24 (1): 16-19

Chaudhary, R.S., Das, A. and Patnaik, U.S. 2003. Organic farming for vegetable production using vermicompost and FYM in Kokriguda watershed of Orissa. Indian Journal of Soil Conservation, 31(2): 203-206

Chinnaswamy, K.N. and Mariakulandai, A. 1966. Influence of organic and inorganic manures on the firmness and storage life of tomato. South Indian Hort., 14: 36-42.

Choudhary, K., More, S.J. and Bhanderi, D.R. 2015. Impact of bio-fertilizers and chemical fertilizers on growth and yield of okra (Abelmoschus esculentus L. Moench). The Ecoscan, 9 (1\&2): 67-70

Choudhary, A.K., Rahi, S., Amar, S. and Yadav, D.S. 2010. Effect of vermicompost and biofertilizers on productivity and profitability in potato in North-Western Himalayas. Curre. Adva. Agri. Sci., 2: 18-21.

Christo, I.E., Okorie, H.A. and Chikere, N.C. 2011.Performance of eggplant (Solanum 
gilo L.) as affected by manure types and rates. Global Res. J. Sci., 1: 43-47.

Congera, A., Anjanappa, M., Inderesh, K.M. and Kumara, B.S. 2013. Effect of integrated nutrient management on tuber dry matter accumulation and uptake of nutrients by potato (Solanum tuberosum L.). Crop Res., 46 (1, 2 \& 3): 174-177.

Desai, A. 1992. Vermiculture application in horticulture. In: Proceedings of the National Science \& Technology. Indian Institute of Technology, Bombay 5: 1014.

Devi, A.K.B. and Roy, A. 2008. Effect of different sources of plant nutrients on yield and economics of cabbage (Brassica oleracea L. var. capitata.). Environment and Ecology, 26 (4C): 2221-2223

Dey, A., Dasgupta, S., Bhattarcharya, S. Chaitanya, A.K., Pati, S. and Pal, B. 2015. Soil physical fertility and performance of potato crop as affected by integration of organic and inorganic fertilizers in new alluvial soil of West Bengal. J. Crop \& Weed, 11(1):132-137

Dimri, D.C., and Singh, V.P. 2006. Responce of farmyard manure nitrogen and row spacing on bulb weight and yield of onion (Allium cepa L.) cv. VL-3. Progressive Horticulture, 37 (1): 185187

FAO, 2017. FAOSTAT. FAO Statistics Division. Food and Agriculture Organization of the United Nations, Rome (Available online at) 〈http://www.fao.org/faostat/en/\#data〉 (Accessed 2 February 2017).

Ghosh, B. C. and Sarkar, S.D. 2000. Recycling of rural wastes in agriculture - An approach for organic farming. Proceedings of Indian Science Congress, 87th Session, Forum for Women and Science, Pune.
Ghuge, M.B., Lekhi, R., Karcho, S. and Kumar, A. 2015. Influence of integrated nutrient management on growth and seed yield of okra (Abelmoschus esculentus (L.) Monech) cv. BRO-6. Environment \& Ecology, 33 (3): 10731076

Gonzalez, M, Gomez, E., Comese, R., Quesada, M. and Conti, M. 2010. Influence of organic amendments on soil quality potential indicators in an urban horticultural system. Bioresource Technology, 101: 8897-8901

Gopakkali, P. and Sharanappa, A. 2014. Effect of organic farming practices on growth, yield, quality and economics of onion (Allium cepa L.) in dry zone of Karnataka. Indian Journal of Agronomy, 59 (2): 336-340

Goswami, L., Nath, A. Sutradhar, S., Bhattacharya, S.S., Kalamdhad, A., Vellingiri, K. and Kim, K.H. 2017. Application of drum compost and vermicompost to improve soil health, growth, and yield parameters for tomato and cabbage plants. Journal of Environmental Management, 200: 243252.

Gruhn, P., Goletti, F. and Yudelman, M. 2000. Integrated nutrient management, soil fertility and sustainable agriculture: current issues and future challenges. IFRPI 2020 Vision Brief.

Gunjal, B. S., Pawar, A. D., Ugale, N. S. and Chitodkar, S. S., 2010, Effect of integrated nutrient management on nutrient uptake and soil fertility of soybean [Glycine Max (L.) Merril]. An Asian J. Soil Sci., 5(2):334-337.

Gupta, A., Sharma, N. and Samnotra, R.K. 2010. Effect of biofertilizers and nitrogen on growth, yield and quality traits in knolkhol (Brassica oleracea L. var. gongylodes). Asian Journal of Horticulture, 5 (2): 294-297 
Harikrishna, B.L., Channal, H.T., Hebsur, N.S., Dharmatti, P.R. and Sarangamath, P.A. 2002. Integrated Nutrient Management (INM) on availability of nutrient uptake and yield of tomato. Karnataka J. Agril. Sci., 15: 275-278

Hedge R. and Rudragouda 2003. Integrated plant nutrient management. Principle and practices, Employment News 3: 2127.

Islam, M.A., Islam, S, Akter, A., Rahman, M.H. and Nandwani, D. 2017. Effect of organic and inorganic fertilizers on soil properties and the growth, yield and quality of tomato in Mymensingh, Bangladesh. Agriculture, 7, 18; doi:10.3390/agriculture7030018

Jaggi, R.C., Dixit, S.P. and Bhardwaj, S.K. 1995. Nutrient uptake and tuber yield of potatoes influenced by phosphate and FYM in an acid alfisol. J. Indian Soc. Soil Sci., 43(3): 391-394.

Jat, L.K., Singh, Y.V., Meena, Y., Meena, S.K., Meena, S.K., Parihar, M., Jatav, H.S., Meena, R.K., and Meena, V.S. 2015. Does integrated nutrient management (INM), enhance agricultural productivity? Journal of Pure and Applied Microbiology, 9 (2): 1211-1221

Jayathilake, P. K. S., Reddy, I.P., Srihari, D. and Reddy, K. R. 2006. Productivity and soil fertility status as influenced by integrated use of n-fixing biofertilizers, organic manures and inorganic fertilizers in onion. The Journal of Agricultural Sciences, 2 (1): 46-58

Jha, M.K., Urraiya, P., Jha, B. and Sahu, M.R. 2017. Effect of organic, inrganic \& biofertilizers on growth attributes of cabbage (Brassica oleracea var. Capitata). Under C.G. Plain zone. Journal of Pharmacognosy and Phytochemistry, 6 (6): 2298-2300

Kadalag, A. D., Jadhav, A. and Raina, R., 2007, Yield and quality of tomato fruits as influenced by bio-fertilizers. Asian, $J$. of Sci., 2 (2): 95-99.

Kale, R. D., Bano, K. and Satyavatai, G. P. 1991. Influence of vermicompost application on growth and yield of cereals, vegetables and ornamental plants. Final report of Karnataka State Council for Science and Technology Project No.67-04 (vermicompost) 3478.

Kamili, L.A., Zargar, M.Y. and Chattoo, M.A. 2002. Effect of microbial inoculants, chemical nitrogen and their combination on brinjal (Solanum melongena L.). Veg. Sci., 29 (1): 87-89.

Kanwar, K. and Paliyal, SS. 2005. Effect of integrated nutrient management on growth and yield of cabbage. Himachal Journal of Agricultural Research, 31(1): $15-20$

Kar, G. 2002. Achieving food security through rainfall revolution. Indian Farming, 52: 3-5.

Kashyap, S., Kumar, S., Maji, S. and Kumar, D. 2014. Effect of Organic manures and inorganic fertilizers on growth, yield and quality of brinjal (Solanum melongena L.) cv. Pant Rituraj. Int. J. Agric. Sci,. 10(1): 305-308.

Kaswan, P K, Yadav, P. K. and Sharma, B. D. 2013. Response of onion (Allium cepa L.) varieties to FYM in arid region of Western Rajasthan. Annals of Horticulture, 6 (1): 30-34

Kattimani, S., 2004. Response of chilli (Capsicum annuum L.) genotypes to integrated nutrient management. M.Sc. (Agri.,) Thesis, Univ. Agri. Sci., Dharwad, Karnataka, India.

Khatic, S. K. and Dikshit, P. R., 2001, Integrated use of organic manure and inorganic fertilizer on yield, quality and economics and nutritions of sunflower grown in Haplustert clay soil. Agric. Sci., 21: 87-90.

Kiraci, S. 2018. Effects of seaweed and different farm manures on growth and 
yield of organic carrots. Journal of Plant Nutrition, 41 (6): 716-721

Kumar, A.B. and Gowda, N.C.N. 2010. Effect of different organic manures and inorganic fertilizers on growth and yield of brinjal (Solanum melongena L.). Asian J. Horti., 5 (2): 444-449.

Kumar, D., Singh, I.P., Singh, B. and Pal, M.K. 2008. Effect of integrated nutrient management on growth attributing parameters in cabbage (Brassica oleracea var. capitata L.). Progressive Agriculture, 8(2): 243-246

Kumar, M. 2012. Productivity and soil health of potato (Solanum tuberosum L.) field as influenced by organic manures, inorganic fertilizers and biofertilizers under high altitudes of eastern Himalayas. Journal of Agricultural Science, 4 (5): 223-234

Kumar, S., Rakesh, K., Sutanu, M., Devendra, K. and Manoj, K., 2014, Effect of organic manures and bio-fertilizers on growth, flowering, yield and quality of tomato cv. Pusa Sheetal. Int. J. Agric. Sci., 10 (1): 329-332.

Kumar, T., Kumar, M., Singh, M.K., Kumar, V., Kumar, A. Kumar, S., and Singh, B. (2013) Impact of integrated nutrient management on growth and economic yield of Okra. (Abelmoschus esculentus (L.) Moench). Annals of Horticulture, 6 (1): $107-114$

Kumar, V. 2016. Use of integrated nutrient management to enhance soil fertility and crop yield of hybrid cultivar of brinjal (Solanum melongena L.) under field conditions. Advances in Plants and Agriculture Res., 4 (2): 00130. DOI: 10.15406/apar.2016.04.00130.

Kumar, V., Saikia, J., Barik, N. and Das, T. 2017. Effect of integrated nutrient management on soil enzymes, microbial biomass carbon and microbial population under okra cultivation.
International Journal of Biochemistry Research \& Review, 20 (4): 1-7

Kumar, Y. K. D., Ananda, M. R., Rehaman, H. M. A., Vishwanath, A. P. and Navi., V. 2006. Nutrient uptake, availability and yield of soybean as influenced by integrated nutrient management. Environment and Ecology, 24 (4):10561058.

Kumaran, S.S., Natarajan, S. and Thamburaj, S. 1998. Effect of organic and inorganic fertilizers on growth, yield and quality of tomato. South Indian Hort., 46 (3-6): 203- 205

Kumari, M and Tripathi, D. 2018. Influence of integrated nutrient management on yield and uptake of tomato (Solanum lycopersicum L.) and availability of nutrients in soil under mid hill conditions of Himachal Pradesh. The Pharma Innovation Journal, 7 (1): 561564

Lal, M. and Khurana, S. C. 2007. Effect of organic manure, biodynamic compost and biofertilizers on growth and yield of potato, grown in potato-onion-guar sequence. Haryana Journal of Horticultural Sciences, 36 (1/2): 142144

Lee, J. 2012. Evaluation of composted cattle manure rate on bulb onion grown with reduced rates of chemical fertilizer. Hort. Technology, 22 (6): 798-803

Lee, S.K., Kader, A.A. 2000. Preharvest and postharvest factors influencing vitamin C content of horticultural crops. Postharvest Biology and Technology, 20: 207-220.

Lisiewska, Z., Kmiecik, W. 1996. Effects of level of nitrogen fertilizer, processing conditions and period of storage of frozen broccoli and cauliflower on vitamin C retention. Food Chem. 57: 267-270.

Madalageri, B. B., Dharmatti, P. R., Hosamani, R. M., Meherwade, M. N. 
and Babalad, H. B., 2006. Effect of nutrition on the physiological maturity of fruit and seed of tomato. Prog. Hort., 21 (3-4): 168-172.

Mahato, P. Badoni, A. and Chauhan, J.S. 2009. Effect of Azotobacter and nitrogen on seed germination and early seedling growth in tomato. Researcher, 1 (4): 62-66.

Mahendran, P.P. and Kumar, N. 1997. Effect of organic manures on cabbage cv. Hero (Brassica oleraceae var. capitata L.). South Indian Horticulture, 45 (5/6): 240-243

Mahendran, P.P. and Kumar, N. 1998. Effect of bio-fertilizer on tuber yield and certain quality parameters of potato $c . v$ Kufri Jyoti, South Indian Horticulture, 46 (1 \& 2): 97-98.

Manjural, H. M, Illia, M. N. and Molla, A. H., 2012. Impact of Trichoderma on growth and yield of tomato. The Agri. Sci. Krishi Foundation., 10 (2): 109-119.

Merentola, Kanaujia, S.P. and Singh, V.B. 2012. Effect of integrated nutrient management on growth, yield and quality of cabbage (Brassica oleracea var. Capitata). Journal of Soils and Crops, 22 (2): 233-239

Ministry of Agriculture and Farmers Welfare, 2017. Final estimate of 2015-16 \& first advance estimates for 2016-17 of area $\&$ production of horticulture crops. Press Information Bureau, Ministry of Agriculture \& Farmers Welfare, Govt. of India

Mitova, I., Dinev, N. and Vassileva, V. 2014. Effects of mineral and organic fertilization on early potato production. Bulgarian J. Agril. Sci., 20 (5): 11821188.

Mohanta, R., Nandi, A.K, Mishra, S.P., Pattnaik, A., Hossain, MM and Padhiary, A.K. 2018. Effect of integrated nutrient management on growth, yield, quality and economics of sprouting broccoli (Brassica oleracea var. italica) cv. Shayali. Journal of Pharmacognosy and Phytochemistry, 8: (1): 2229-2232

Moradi, S. 2015. Impact of sheep manure, urea and triple superphosphate on onions morphological properties. International Journal of Farming and Allied Science,s 4 (2): 167-170

Mrinal, S., Rajkhowa, D. J. and Saikia, M. 1998. Effect of planting density and vermicompost on yield of potato raised from seedling tubers. Journal of the Indian Potato Association, 25 (3-4): 141-142.

Mujawar, J.U. 2012. Effect of organic and inorganic sources of nutrients on soil fertility and yield of brinjal (Solanum melongena L.) M.Sc. (Ag.) Thesis, University of Agricultural Sciences, Dharwad, Karnataka, India.

Munshi, S.K. 2014. Utilization of organic waste compost for brinjal production. African J. Agric. Sci. \& Tech., 2(1): 4653.

Nag, G.P. 2006. Integrated nutrient management in potato for Chhattisgarh plains. M. Sc. (Ag.) Thesis, Indira Gandhi KrishiVishwavidyala, Raipur, pp. 95.

Najar, I.A.; Khan, A.B. and Hai, A. 2015. Effect of macrophyte vermicompost on growth and productivity of brinjal (Solanum melongena L.) under field conditions. Int. J. Recycling Org. Waste in Agric., 4 (2): 73-83.

Nanthakumar, S. and Veeraragavathatham, D. 1999. Effect of integrated nutrient management on yield and quality attributes of brinjal (Solanum mélongena L.). South Indian Hort., 47 (1-6): 81-85.

Natarajan, Kumaran, S. and Thamburaj, S., 2004. Effect of organic and inorganic fertilizers on growth and yield of 
Tomato. South Indian Hort., 50 (4-6): $522-526$.

National Research Council. 1991. Integrated Nutrient Management for Crop Production. Toward Sustainability: A Plan for Collaborative Research on Agriculture and Natural Resource Management. Washington, DC: The National Academies Press. doi: $10.17226 / 1822$

Nurhidayati, N., Ali, U. and Murwani, I. 2016. Yield and quality of cabbage (Brassica oleracea L.var. Capitata) under organic growing media using vermicompost and earthworm Pontoscolex corethrurus inoculation. Agriculture and Agricultural Science Procedia, 11 (6): 5 - 13

Padamwar, S.B. and Dakore, H.G. 2009. Influence of organic fertilizer on morphological and nutritional parameter of cauliflower. Bioinfolet, 6 (2): 88-90

Patil, M.B., Mohammed, R.G. and Ghadge, P.M. 2004. Effects of inorganic and organic fertilizers on growth, fruit yield and quality of tomato. J. Maharashtra Agric. Univ., Pune 29 (2): 124-127.

Patil, M.P., Hulamani, N.C., Athani, S.I. and Patil, M.G. 1997. Response of Potato (Solanum tuberosum L.) cv. Kufri Chandramukhi to integrated nutrient management. Adva. Agri. Rese. Ind., 8: 135-139.

Patil, P. V., Chalwade, P. B., Solanke, A. S. and Kulkarni, V. K. 2005. Effect of fly ash and FYM on nutrient uptake and yield of onion. Journal of Soils and Crops, 15 (1): 187-192

Pervez, M.A., Muhammad, F. and Ullah, E. 2000. Effects of organic and inorganic manures on physical characteristics of Potato (Solanum tuberosum L.). Int. J. Agri. \& Bio., 1560-8530.

Prabhakar, M., Hebbar, S.S. and Nair, A.K. 2012. Effect of organic farming practices on growth, yield and quality of rose onion (Allium cepa). Indian Journal of Agricultural Sciences, 82 (6): 500-03.

Prabhakar, M., Hebbar, S.S.. Nair, A.K Panneer Selvam, P. Rajeshwari, R.S. and Kumar, P. 2017. Growth, yield and quality of onion (Allium Cepa L.) as influenced by organic farming practices. Int.J.Curr.Microbiol.App.Sci. $6 \quad$ (8): 144-149

Prabhu, P. P., Vani, A. S. and Jitender, T. R., 2010, Effect of organic fertilizer on rhizosphere, growth and yield of tomato. Acta Hort., 685: 313-314.

Prabhu, T. A.K., Sajindranath, R.G., Dange, V.M., Munde, N.G. and Rathod, A 2006. Effect of integrated nutrient management on seed yield and seed qualities in okra cv. Prabhani Kranti. Annals of Plant Physiology, 20 (1): 3840.

Prabhu, T., Narwadkar, P.R., Sajindranath, A.K., Mohd, R. 2002. Integrated nutrient management studies in okra. South Indian Hort., 50 (4/6): 550-553.

Prasad, V.M. and Gaurav, K. 2004. Effect of manure and biofertilizer on growth and yield of sprouting broccoli $\mathrm{cv}$. Aishwarya. Proceedings of the first Indian Horticulture Congress. New Delhi. November 6-9: 249

Prativa, K. C., and Bhattarai, B. P., 2011. Effect of integrated nutrient management on the growth, yield and soil nutrient status in tomato. Nepal $J$. of Sci. and Tech., 12: 23-28.

Premshekhar, M. and Rajashree, V., 2009. Influence of bio-fertilizer on the growth characters, yield attributes, yield and quality of tomato. American Eurasian J. of Sustainable Agric., 3 (1): 68-70.

Raj, A.K. and Kumari, G. 2001. Effect of organic manures and Azospirillum inoculation on yield and quality of okra (Abelmoschus esculentus (L.) Moench). Veg. Sci., 28 (2): 179-181. 
Ramesh, P., Panwar, N. R., Singh, A. B. and Ramana, S. 2008. Effect of organic manures on productivity, soil fertility and economics of soybean (Glycine max) - durum wheat (Titicum durum) cropping system under organic farming in Vertisols. Indian J. Agril. Sci., 78 (12): 118-122.

Ravindrababu, M. 1999. Studies on integrated nutrient management with vermicompost and inorganic fertilizers in carrot (Daucus carota L.). M Sc (Hort.) Thesis submitted to Acharya N G Ranga Agricultural University, Hyderabad

Ray, R., Patra, S.K., Ghosh, K.K., Shahoo, S.K. 2005. Integrated nutrient management in okra in a river basin. Indian J. Hort. 62 (3): 260-264.

Reddy, B.G. and Reddy, M.S. 1999. Effect of integrated management on soil available micronutrients in maize-soybean cropping system. Journal of Research ANGRAU, 27: 24-27

Reddy, K. C. 2000. Studies on integrated nutrient management with vermicompost and nitrogenous fertilizer in onion (Allium cepa L.) - Radish (Raphanus savitus L.) cropping system for sustainable crop production. $\mathrm{Ph} \mathrm{D}$ Thesis submitted to Acharya N G Ranga Agricultural University, Hyderabad.

Reddy, K. C. and Reddy, K. M. 2005. Differential levels of vermicompost and nitrogen on growth and yield in onion (Allium cepa L.) and radish (Raphanus sativus L.) cropping system. Journal of Research ANGRAU, 33 (1): 11-17

Sachan, S., Singh, D., Kasera, S., Mishra, S.K., Tripathi, Y., Mishra, V. and Singh, R.K. 2017. Integrated Nutrient Management (INM) in okra (Abelmoschus esculentus (L.) Moench) for better growth and higher yield. Journal of Pharmacognosy and Phytochemistry, 6 (5): 1854-1856
Santlal, 2003. Effect of nitrogen in the form of urea and bulky organic manure on potato production. M.Sc. (Ag) Thesis, Department of Horticulture, Indira Gandhi Agricultural University, Raipur. Sarangthem, I., Misra, A.D. and Chakraborty, Y. 2011. Cabbage productivity, nutrient uptake and soil fertility as affected by organic and biosources. Agricultural Science Digest, 31 (4): 260

Sarkar, A., Sarkar, S. and Zaman, A. 2011.Growth and yield of potato as influenced by combination of organic manures and inorganic fertilizers. Potato J., 38 (1): 78-80.

Sayed, F., Sayed.El., Hassan, A. H., Mohamed, M., Mogy, E. 1. and Abdel, A.W. 2014. Growth, yield and nutrient concentration of potato plants grown under organic and conventional fertilizer systems. American-Eurasian J. Agric. \& Environ. Sci., 14 (7): 636-643.

Shalini, S.B., Channal, H.T., Hebsur, N.S., Dharmatti, P.R. and Sarangamath, P.A. 2002. Effect of integrated nitrogen management on nutrient uptake in Knol-khol, yield and nutrient availability in soil. Karnataka Journal of Agricultural sciences, 15 (1): 43-46

Sharma, J., Rattan, P. and Kumar, S. 2012. Response of vegetable crops to use of integrated nutrient management practices. SABB Journal of Food and Agriculture Science, 2(1): 15-19

Sharma, N., Gupta, A., and Samnotra, R. K., 2010. Effect of integrated nutrient management on growth yield and quality parameters in tomato. The Asian J. of Hort., 5: 314-317.

Sharma, R. A. and Raghu, J. S. 2003. Evaluation of sustainable nutrient management practices based on land degradation and rainfall effects on soybean yield and organic carbon and available $\mathrm{N}$ content in rainfed Vertisols. 
Annales Universitatis Mariae Curie Sectio E, Agricultura, 58:205-221

Shree, S., Singh, V.K. and Kumar, R. 2014. Effect of integrated nutrient management on yield and quality of cauliflower (Brassica oleracea var. Botrytis L.). The Bioscan, 9 (3): 10531058

Singh, A. B., Saha J. K. and Ghosh P. K. 2008. Effect of nutrient management practices on soybean (Glycine max) chickpea (Cicer arietinum) cropping system for improving seed yield, quality and soil biological health under rainfed condition. Indian J. Agril. Sci., 78 (6): 485-489.

Singh, B. and Kumar, S. 2016. Effect of integrated nutrient management on growth, yield and nutrient uptake of clusterbean (Cyamopsis tetragonoloba) under irrigated conditions. Agric. Sci. Digest., 36 (1): 35-39

Singh, K. 2000. Challenges in vegetable production in twenty first century, in emerging scenario in vegetable research and development. Ed. G. Kallo and Singh, K. pp. 334-36.

Singh, L, Bhonde, S. R. and Mishra, V. K. 1997. Effect of different organic manures and inorganic fertilizers on yield and quality of Rabi onion. National Horticultural Research Development Foundation, Newsletter 17 (3): 1-3

Singh, M., Biswas, S.K., Nagar, D., Lal, K. and Singh, J. 2017. Impact of Biofertilizer on growth parameters and yield of Potato. Int. J. of Current Microbiology and Applied Sciences, 6: 1717-1724.

Singh, S. K., Trivedi, J. and Markam, S. K., 2014, Effect of different combinations of organic manurer and chemical fertilizers on growth of tomato. Indian Hort. J., 4 (1): 14-18.
Singh, T.R., Singh, A., Singh, S.K., Singh, M.P. 2004. Influence of integrated nutrient management on properties of a mollisol under okra-pea-tomato cropping sequence. Agropedology, 14 (2): 92-95.

Singh, V.K., Shree, S., Kumar, R., Singh, P and Singh, R.G. 2015. Effect of microbial inoculants and inorganic fertilizers on growth and yield of hybrid cabbage (Brassica oleracea L. var.Capitata). The Bioscan, 10 (3): 1227-1231

Singh, Y.P., Yadav, L.M., Kumar, J., Prasad, S.S. and Mishra, A.K. 2018. Effect of organic farming on yield, yield parameters and storage quality of onion (Allium Cepa L). Journal of Pharmacognosy and Phytochemistry, 7 (1): 1751-1753

Solanke, A.V., Shete, B.T. and Dhage, V.J. 2009. Growth and yield of potato as influenced by integrated nutrient management. Anna. Plant Physio., 23 (2): 189-191.

Sood, M.C. 2007. Integrated nutrient supply and management for potato production in mid Hills of Shimla. Potato J., 34 (12): 101-102.

Suchitra, S. and Manivannan, K. 2012. Studies on the influence of organic inputs on the growth and fruit yield of brinjal in various seasons. Ind. $J$. Fundamental and App. Life Sci. 2 (4): 61-64.

Sudhakar, P. S. and Purushotham, K., 2008. Studies on effect of bio-fertilizer on growth, yield and quality of tomato (Solanum lycopersicum L.). The Orissa J. of Hort., 36 (2): 120-125.

Suge, J.K., Omunyin, M.E. and Omani, E.N. 2011. Effect of organic and inorganic sources of fertilizer on growth, yield and quality of eggplant (Solanum melongena L.). Arch. Appl. Sci. Res., 3 (6): 470-479. 
Sujatha, N.T. and Krishnappa, K.S. 1995. Quality attributed of potato tubers as influenced by different fertilizer levels. South Ind. Horti., 43(5-6): 128- 130.

Talwar, D., Singh, K., Varinder, S. and Jagdish, S. 2016. Growth, yield and quality of onion as influenced by integrated nutrient management. International Journal of Agriculture Sciences, 8 (51): 2295-2298

Tanwar, S. P. S. and Shaktawat, M. S. 2004. Integrated phosphorus management in soybean-wheat cropping system in Southern Rajasthan. Fert. News, 49 (8):25-28, 31-34.

Tekale, G. S., Saravaiya, S. N., Jadhav, P. B., Tekale, C. D. and Patel, R. P. 2017. Integrated Nutrient Management (INM) on nutrient availability, uptake and yield of tomato (Lycopersicon esculentum Mill.) cv. "Gujrat Tomato-2". Int.J.Curr.Microbiol.App.Sci., 6 (5): 864-874.

Toor, R.K. Savage, G.P., Heeb, A. 2010. Influence of different types of fertilisers on the major antioxidant components of tomatoes. J. Food Compos Anal., 19, $20-27$.

Tripathy, P., and T.K. Maity 2009. Impact of Integrated nutrient management on fruit quality and yield of okra hybrids. Crop Research Hisar, 37 (1/3): 101-106.

Tripathy, P., Bhattacharyay, B. and Maity, T.K. 2004. Response of okra (Abelmoschus esculentus L. Moench) to integrated nutrient management system. Orissa J. Hort., 32 (2): 14-18.

Tripathy, P., T.K., Maity, H.P., Patnaik (2008). Field reaction of open pollinated okra varieties to major pest under integrated nutrient management system. Indian J. Entomology, 70 (3): 250-254.

Ullah, M.S., Islam, M.S., Islam, M.A. and Haque, T. 2008. Effects of organic manures and chemical fertilizers on the yield of brinjal and soil properties. $J$. Bangladesh Agril. Univ. 6(2): 271-276.

Vijay, K.S. and Seethalakshmi, S. 2011. Response of egg plant (Solanum melongena L.) to integrated nutrient management amended soil. Int. J. of Sci. Engineer, 2 (8): 1-8.

Wang, D., Shi, Q., Wang, X.M., Wei, M. Hu, Liu, J. Yang, F. 2010. Influence of cow manure vermicompost on the growth, metabolite contents, and antioxidant activities of Chines cabbage (Brassica campestris sp.chinensis). Biol Fertil Soils, 46: 689-696

Witt, C. and Dobermann, A. 2004. Toward a decision support system for site-specific nutrient management. In: Dobermann, A., Witt, C. and Dawe, D. (Eds.), Increasing the productivity of intensive rice systems through site-specific nutrient management. Science Publishers, Inc., and International Rice Research Institute (IRRI), Enfield, NH (USA) and Los Baños (Philippines), 359-395.

Yadav, S.K. and Shrivastava, A.K. 2015. A review on agronomical aspects of potato production northern-eastern region of India. Int. J. Applied and Pure Science and Agri., 1(6):26-34.

Yadav, V. S. and Yadav, B. D. 2001. Effect of NICAST (organic manure) in comparison to recommended doses of manure and fertilizers in onion. South Indian Horticulture, 49: 160-161

Yadu, D. 2011. Effect of varying levels of NPK fertilizers and size of seed tubers on growth and yield of potato (Solanum tuberosum L.) in Alfisol. M. Sc. (Ag.) Thesis, Indira Gandhi Krishi Vishwavidyala, Raipur.

Yeptho, A K, Singh, A. K, Kanaujia, S. P. and Singh, V. B. 2009. Effect of organic manures and biofertilizers on yield and nutrient composition of onion. 
Environment and Ecology, 27(4): 16281630

Yeptho, V. K., Singh, V. B. and Amod, S. 2010. Effect of integrated nutrient management on growth, yield and quality of tomato under poly house condition. J. Soils and Crops, 22 (2): 246-252.

Zainub, B., Ayub, G., Siddique, S., Zeb, S. and Jamil, E. 2016. Response of brinjal (Solanum melongena L.) cultivars to nitrogen levels. Pure Applied Biology, 5(1): 134-141.

Zhang, F. S., Cui, Z. L., Fan, M. S., Zhang, W. F., Chen, X. P., and Jiang, Q. F. 2011. Integrated soil-crop system management: Reducing environmental risk while increasing crop productivity and improving nutrient use efficiency in China. J. Environ. Qual., 40: 1-7.

Zhang, F. S., Shen, J. B., Li, L., and Liu, X. 2004. An overview of rhizosphere processes related with plant nutrition in major cropping systems in China. Plant Soil, 260: 89-99.

Zhang, F., Cui, Z., Chen, X., Ju, X., Shen, J., Chen, Q., Liu, X., Zhang, W., Mi, G., Fan, M. and Jiang, R. 2012. Integrated nutrient management for food security and environmental quality in China. Adv. Agron., 116: 1-40.

Zhang, F., Shen, J., Zhang, J., Zuo, Y., Li, L., and Chen, X. 2010. Rhizosphere processes and management for improving nutrient use efficiency and crop productivity: Implications for China. Adv. Agron., 107: 1-32.

\section{How to cite this article:}

Mukesh Kumar, Veena Chaudhary, R.K. Naresh, O.P. Maurya and Pal, S.L. 2018. Does Integrated Sources of Nutrients Enhance Growth, Yield, Quality and Soil Fertility of Vegetable Crops: A Review. Int.J.Curr.Microbiol.App.Sci. 7(06): 125-155. doi: https://doi.org/10.20546/ijcmas.2018.706.017 